\title{
Pitfalls in the chemistry of cellulosic key chromophores
}

\author{
Hubert Hettegger $\cdot$ Hassan Amer • Nele S. Zwirchmayr • Markus Bacher • \\ Takashi Hosoya $\cdot$ Antje Potthast $\cdot$ Thomas Rosenau 10
}

Received: 1 October 2018/ Accepted: 8 November 2018/Published online: 30 November 2018

(C) The Author(s) 2018

\begin{abstract}
The chemistry of cellulosic key chromophores is challenging because of the usually very low concentration of the colored compounds in realworld cellulosic matrices. It offers many surprises and positive outcomes; unfortunately there are also pitfalls and disappointments. This report discusses eight examples or surprising chemistry out of the realm of cellulosic key chromophores. The reactions have
\end{abstract}

either taken unforeseen paths or provided unexpected products. The reaction mechanisms of the "strange" processes are described and the products are comprehensively analytically characterized. Given that the seemingly obvious approaches have failed, alternatives for obtaining the desired products are provided, wherever possible.

Hubert Hettegger and Hassan Amer have contributed equally to this work.

H. Hettegger · H. Amer - N. S. Zwirchmayr .

M. Bacher · A. Potthast · T. Rosenau ( $\square)$

Division of Chemistry of Renewable Resources,

Department of Chemistry, University of Natural

Resources and Life Sciences, Muthgasse 18, 1190 Vienna,

Austria

e-mail: thomas.rosenau@boku.ac.at

H. Amer

Department of Natural and Microbial Products Chemistry, National Research Centre, 33 Al Bohous St., Dokki,

Giza 12622, Egypt

T. Hosoya

Graduate School of Life and Environmental Sciences,

Kyoto Prefectural University, Shimogamo-hangi-cho

11-5, Sakyo-ku, Kyoto-shi, Kyoto, Japan

T. Rosenau

Johan Gadolin Process Chemistry Centre, Åbo Akademi

University, Porthansgatan 3, 20500 Åbo/Turku, Finland 


\section{Graphical abstract}

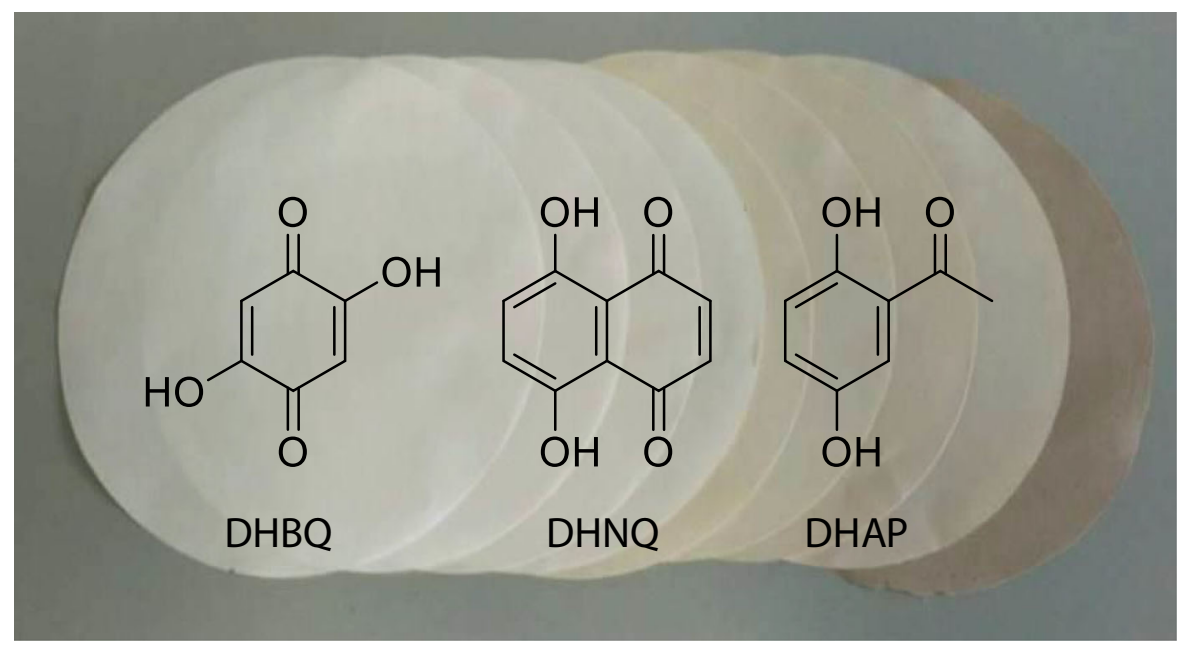

Keywords Aging - Hydroxy-benzo-[1,4]-quinones · Bleaching · Cellulose · Chromophores · Hydroxynaphtho-[1,4]-quinones · Pulp · Brightness reversion · Hydroxy-acetophenones

\section{Introduction}

The chemistry of bleaching is a branch of cellulose science. In principle, a large part of the pulp and paper industries has been devoted to the destruction of chromophores in pulp and to the production of brighter and whiter products. Almost innumerable combinations of bleaching sequences are used in the bleaching plants worldwide, and a large percentage of the chemicals and the water required for pulp production is spent during bleaching. Recently, the current state of the art of pulp bleaching was authoritatively summarized (Suess 2010).

With the determination of the key chromophores in pulp in accordance with the chromophore release and identification (CRI) method (Rosenau et al. 2004a, 2005a, b), there has been renewed interest in bleaching chemistry. For the first time, the defined chemical structures of cellulosic chromophores have become accessible. Previously the likely structural motifs, such as quinones, conjugated double bonds or metal complexes had only been hypothesized (Suess and Filho 2003). The generally very low concentrations of individual chromophoric compounds, ranging from the low ppm to the ppb scale, have been the main obstacles to their analytical detection and identification. The general chemistry, especially the bleaching chemistry, of the three cellulose key chromophore classes, 2,5-dihydroxy-[1,4]-benzoquinones (DHBQ, 1), 5,8-dihydroxy-[1,4]-naphthoquinones (DHNQ, 2) and 2,5-dihydroxyacetophenones (DHAP, 3) (Fig. 1), have been studied extensively (Korntner et al. 2015) and recently reviewed (Hosoya et al. 2013a, b, 2015). They are especially stabilized by H-bonds in acidic medium and by resonance in neutral and alkaline media. Their dianions are characterized by extensive double bond delocalization (Fig. 1); thus their reaction with common bleaching agents is much slower than that of other chromophores that lack such stabilization effects. It was reasonable to assume that industrial bleaching operations can be streamlined once the defined chemical nature of the main chromophores becomes known. There are several examples of the successful transfer of results and conclusions from mechanistic bleaching studies to industrial practice.

In the laboratory, chemists can work with much higher concentrations of the chromophoric compounds so that they can be more easily manipulated and better used in separation, purification and general analytical steps. In the meantime, many studies have addressed the chemistry of cellulosic key chromophores-this study contributes to this fascinating area of cellulose chemistry. However, this kind of chemistry can sometimes be rather complex and tricky. There are often curved roads and detours instead of wide paths. Especially in chromophore 
<smiles>CC=CC1=CC(=O)C(=O)C(=O)C1O</smiles>

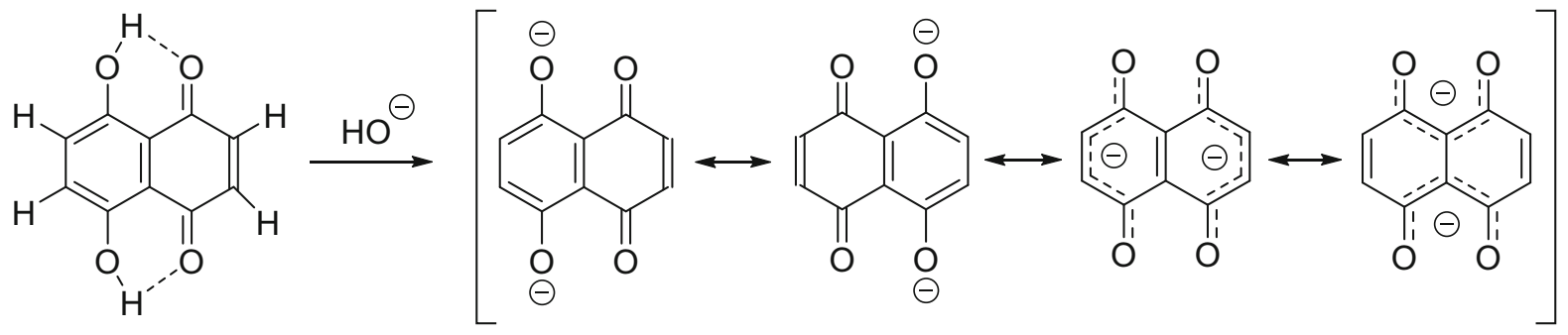

DHNQ (2)<smiles></smiles>

DHAP (3)

Fig. 1 Formulae of the three cellulosic key chromophores DHBQ (1), DHNQ (2), and DHAP (3). The compounds exhibit special stabilization in acidic medium by H-bonding and in neutral to alkaline medium, in the form of their respective (di)anions, by resonance

chemistry, phrases such as "this paved the road" or "a new avenue to", often used to describe the importance of a new finding, most likely implied that the broad avenues and paved roads were rather bumpy winding tracks, at least in the beginning.

Based on the authors' decade-long engagement with cellulosic chromophores, the current work reports on the failures and pitfalls in the study of the chemistry of these compounds. This report focuses on cases in which the chemical "common sense" was confounded and the expectations based on textbook chemistry were not borne out. It must be noted that not all of the cases were complete failures, however. Some of them have led to interesting mechanistic insights; they all increased the general understanding of chromophore chemistry. In each of these cases the outcome was different from the expected one, and the reactions occurred in surprising ways. It is hoped that this report will not be regarded as an attempt to publish chemistry studies that are considered useless-because they were initially unsuccessful. Indeed, an honest description of the failures can help others to avoid such pitfalls in the future and prevent them from stumbling upon the same problems again.

\section{Results and discussion}

Attempted acetylation of DHBQ in pyridine/acetic anhydride

2,5-Dihydroxy-[1,4]-benzoquinone (DHBQ, 1) is the most prominent cellulosic key chromophore (Hosoya et al. 2013a, b). Its predominance has been attributed 
to its particular resonance stabilization with delocalized double bonds. It is thus a prime survivor of bleaching attempts. It persists long after other chromophores-that lack this special type of stabilization-have been degraded (Hosoya and Rosenau 2013). The stability of the compounds is based on the easy formation of a very stable dianion, which requires the deprotonation of the two hydroxyl groups, both of which are rather acidic. As with many cases, the stability of the anion is the driving force for the ready deprotonation of the acid, i.e. its higher acidity. For example, it is reasonable to attempt to protect the $\mathrm{OH}$ groups. This would "anchor" the double bonds in the quinoid system and thus render the compounds more easily attackable by bleaching agents.

An attempted acetylation of DHBQ under standard conditions (acetic anhydride/pyridine) yielded surprising results. The expected diester, 2,5-diacetoxy[1,4]-benzoquinone (4), was not formed (Fig. 2); however, there were quite high yields (between 52 and $87 \%$ ) of only one defined product, 3-(4-pyridyl)1,2,4,5-tetraacetoxybenzene (5). The product was comprehensively analytically characterized, and a crystal structure was obtained (Fig. 2) (Krainz 2009). Formally, the reaction can be characterized as $\mathrm{C}-\mathrm{C}$ coupling, or as a redox process in which the two coupled carbon atoms are formally oxidized while the benzoquinoid system is reduced to an aromatic unit. However, the detailed mechanism remains unclear. Radical processes were considered rather unlikely causes, given the lack of EPR signals and effects of addition of antioxidants or careful exclusion of oxygen while the reaction was being performed. A similar reaction with other amine catalysts, such as triethylamine or DABCO afforded neither the initially targeted acetylation product $\mathbf{4}$ nor any coupling product. The use of acridine, 2-methylpyridine, and 2,6-dimethylpyridine resulted in analogous coupling products in lower yield $(11 \%, 23 \%$ and $44 \%$, respectively). In contrast, 4-dimethylaminopyridine and 4-methylpyridine, with their 4-position blocked by the substituent, did not exhibit the reaction. Replacing acetic anhydride with trimethylsilyl chloride under ambient conditions, to obtain the $O$-trimethylsilyl ethers, provided an intractable mixture from which no defined products could be isolated. Other anhydrides, such as propionic anhydride or hexanoic anhydride, afforded analogous coupling products in lower yields (13\% and $18 \%$, respectively) besides black precipitates, probably an oligomerized/polymerized material, but again, no bis-acylation products of DHBQ (1).

Satisfying yields of the desired bis-acetylation product 4 can be obtained if the esterification is catalyzed by acids (Fig. 3); however, this did not<smiles>CC(=O)Oc1cc(OC(C)=O)c(-c2ccncc2)c(OC(C)=O)c1OC(C)=O</smiles>

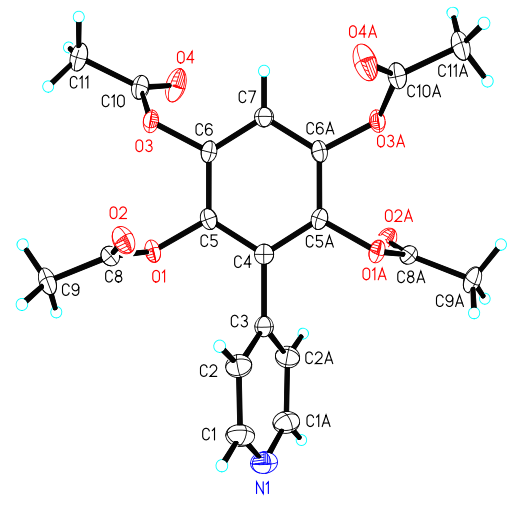

Fig. 2 Attempted acetylation of DHBQ (1) in acetic anhydride/pyridine afforded 3-(4-pyridyl)-1,2,4,5-tetraacetoxy-benzene (5) as the main product. Right: x-ray structure (40\% thermal ellipsoid plot) of 3-(4-pyridyl)-1,2,4,5-tetraacetoxy-benzene (5) 
<smiles>O=C1C=C(O)C(=O)C=C1O</smiles><smiles>CC(=O)OC1=CC(=O)C(OC(C)=O)=CC1=O</smiles><smiles>O=C1C=C(O)C(=O)C=C1O</smiles>

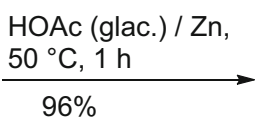<smiles>CC(=O)Oc1cc(OC(C)=O)c(OC(C)=O)cc1OC(C)=O</smiles>

Fig. 3 Successful bisacetylation and reductive peracetylation of DHBQ (1)

occur under any basic conditions. The reactivity of the resonance-stabilized dianion, which is immediately formed in the presence of the base, clearly did not allow for the localization of the negative charge to two of the oxygens. This would be a prerequisite for a nucleophilic attack at the anhydride. Also some indications of reactions at the "free" C-3 and C-6 positions of DHBQ were found: the proton integrals in the ${ }^{1} \mathrm{H}$ NMR spectra decreased over time (not because of simple $\mathrm{H}-\mathrm{D}$ exchange). The reaction of $\mathbf{1}$ in glacial acetic acid catalyzed with $0.5 \%$ concentrated sulfuric acid and short reaction times $(<5 \mathrm{~min})$ gave the best yields of 4 (approximately 85\%). Care must be taken that the reaction times are kept below $10 \mathrm{~min}$, as the yields drop to $60 \%, 38 \%$ and $23 \%$ after 15,30 and 60 min reaction time, respectively.

Another approach to converting DHBQ into a stable acetyl derivative was acetylation under reductive conditions, with the use of acetic anhydride/Zn powder (Fig. 3). The yields of 1,2,4,5-tetraacetoxybenzene (6) were excellent (96\%). The reaction thus effected the reduction of the quinone to the corresponding tetraphenol intermediate which was simultaneously peracetylated. While DHBQ is strongly colored, $\mathbf{6}$ is colorless in its pure form.

Attempted acylation/alkylation of DHBQ in the presence of dimethyl sulfoxide (DMSO)

The dianion of DHBQ (1) and the anion of the chromophore 2-hydroxy-[1,4]-naphthoquinone (7) exhibit strong resonance stabilization and delocalization of the negative charge(s) and double bonds (Rosenau et al. 2007). In principle, they contain 1,3- dicarbonyl structures in their enol form which can be readily deprotonated to the corresponding enolate. Consequently, acylation or alkylation reactions should be possible at the oxygen or $\beta$-carbon atoms, in accordance with the chemistry of enolates. This would afford $O$-substituted or 3,6-disubstituted DHBQ derivatives, respectively.

When such reactions were carried out in DMSO as the solvent, or in the presence of the DMSO leftover from previous reactions or purification operations, the outcome was very different from the predictions. From DHBQ, a bis(sulfonium ylide) (8) was formed, which resulted from a coupling of the chromophore with DMSO on both "sides" of the DHBQ molecule; and naphthoquinone derivative 7 provided the analogous mono(sulfonium ylide) 9 (Fig. 4) (Rosenau et al. 2002, 2004b). These sulfonium ylides are extremely stable compounds that in most cases precipitate out of the reaction mixtures as bright yellow, crystalline precipitates (fine needles). Their crystal structures are shown in Fig. 4. The reaction seemed to be favored because minor amounts of DMSO $(<0.01$ vol\% of the bulk solvent) caused the precipitate to be formed. In $\mathrm{DMSO} / \mathrm{methyl}$ iodide/ $\mathrm{NaOH}$ (a typical mixture for $O$ methylation of hydroxyl groups) or in DMSO/acetic anhydride/cat. $\mathrm{H}_{2} \mathrm{SO}_{4}$ (a typical mixture for base-free esterification) the formation of the bis(sulfonium ylide) from DHBQ was nearly quantitative.

So far, alkylation or acylation of DHBQ (1) at positions 3 and 6 were not achieved, and also the $O$ alkylation (at O-2 and O-5) failed. The attempts with 2,5-bis $(O$-acylation $)$ have already been addressed above. Solvents other than DMSO did not provide the intended alkyl/acyl derivatives, and variations of the reaction conditions (temperature, solvents, and concentrations) were similarly unsuccessful.

\section{Attempted acetylation of DHAP}

DHAP (2,5-dihydroxyacetophenone, 3 ) and its isomer 2,6-dihydroxyacetophenone (10) are dihydroxybenzenes (Hosoya et al. 2015). Especially for compound $\mathbf{3}$, a hydroquinone derivative, easy oxidation would be expected to occur, even merely by contact with the ambient air. One obvious way to render the compounds more stable, for instance for analytical studies (Schedl et al. 2017), is to protect the phenolic (aromatic) hydroxyl groups. This can be done most easily in the form of the respective bisacetate. 


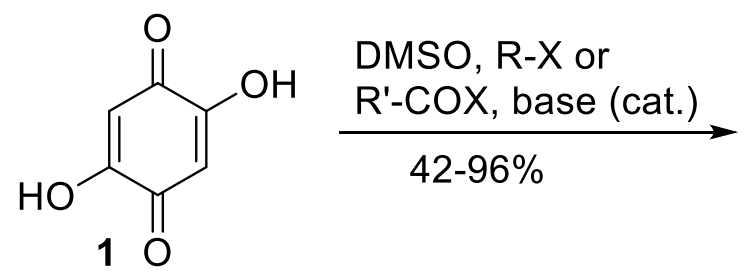<smiles>CS(C)([O-])C1C(=O)C(=O)C(S(C)(=O)=O)C(=O)C1=O</smiles>

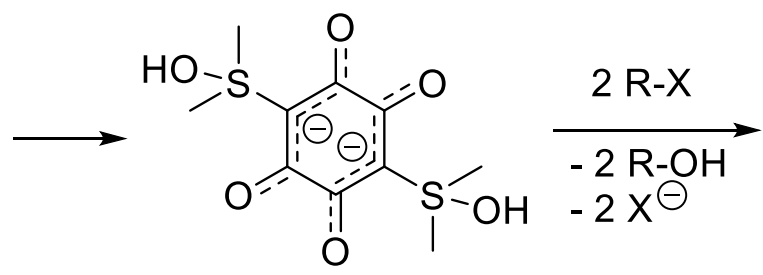<smiles>Cc1c([S+](C)C)c(=O)c(=O)c1=O</smiles><smiles>O=C1C=C(O)C(=O)c2ccccc21</smiles>

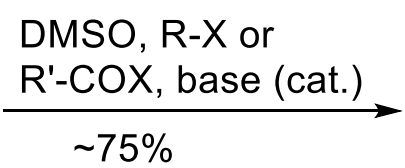<smiles>C[S+](C)C1=C(O)C(=O)c2ccccc2C1=O</smiles>

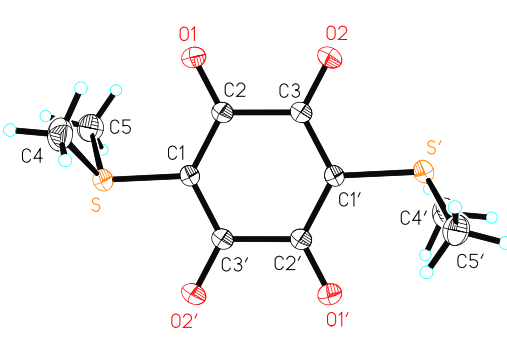

Fig. 4 Reaction of DHBQ (1) and 2-hydroxy-[1,4]-naphthoquinone (7) with alkylating (or acylating) reagents in the presence of DMSO, producing very stable sulfonium ylides $(\mathbf{8}$, 9) instead of the expected $O$-alkylated $(O$-acylated) derivatives.

However, the acetylation of $\mathbf{3}$ under standard conditions, acetic anhydride/pyridine at room temperature (r.t.) provided the 5-monoacetate (2-hydroxy-5-acetoxy-acetophenone, 11) in very good yields (82\%), along with some byproducts (see below), but not the desired diacetate 12. The situation in case of isomer $\mathbf{1 0}$ as the starting material was quite similar: $74 \%$ of the monoacetate 2-hydroxy-6-acetoxy-acetophenone (13) was formed, but again there was no diacetate 14 (Fig. 5). In neither case were 2-mono-acetoxy compounds observed. The reason for this regioselectivity

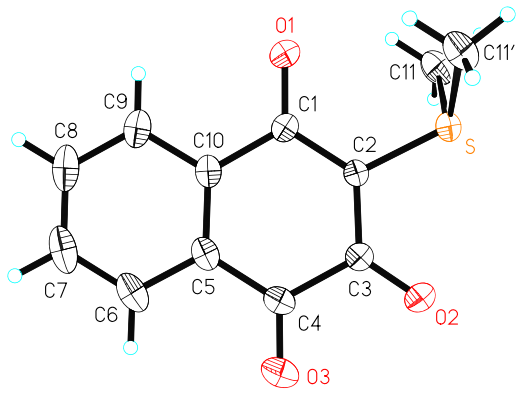

Bottom left: crystal structure (40\% thermal ellipsoid plot) of bis(dimethylsulfonium ylide) 8 . Bottom right: crystal structure (40\% thermal ellipsoid plot) of dimethylsulfonium ylide 9

was easily recognized. The very strong hydrogen bond from the 2-OH to the neighboring acetyl-carbonyl blocked this phenolic hydroxyl from acetylation and rendered it inert.

Even more surprising than the effect per se was the extent of this $\mathrm{OH}$-passivation: extending the reaction times to 3 days had no effect. Increasing the reaction temperature boosted the amount and number of byproducts at the expense of the monoacetate (see Table 1), but it did not offer any improvement with regard to the diacetates. In the case of other common 
<smiles>[X]CC(=O)c1cc(OC(C)=O)ccc1OC(C)=O</smiles>

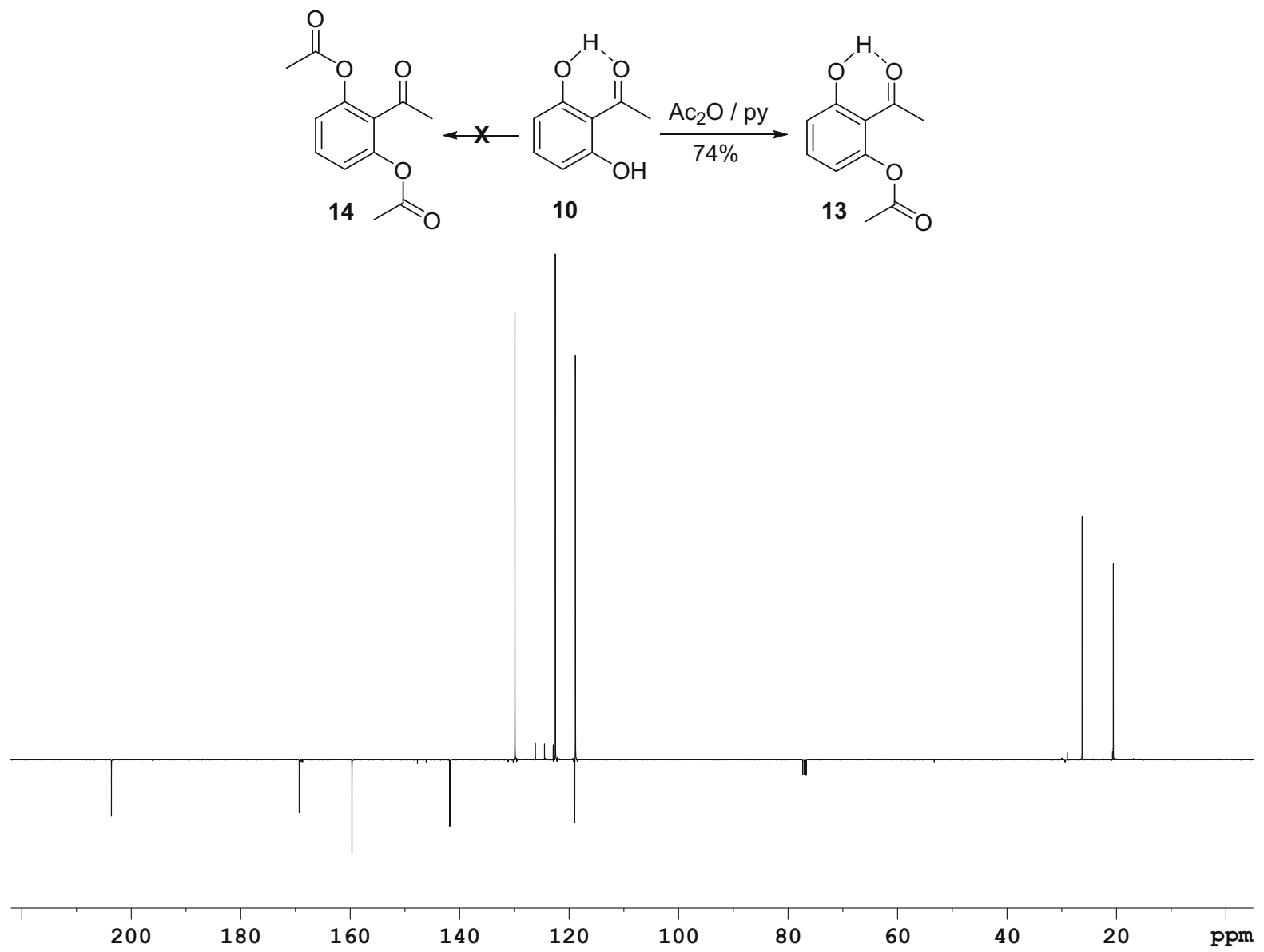

Fig. 5 Attempted peracetylation of $\operatorname{DHAP}(\mathbf{3})$ and its isomer $\mathbf{1 0}$ under mild conditions (r.t., 2 h) produced the monoacetates (11 and $\mathbf{1 3}$, respectively), but not the expected diacetates. Bottom: ${ }^{13} \mathrm{C}$ NMR spectrum of the DHAP 4-O-monoacetate (11)

basic catalysts (DMAP, TEA, or DBU) in combination with elevated reaction temperature $\left(80^{\circ} \mathrm{C}\right)$, the byproducts reached levels similar to the monoacetates. This prompted a closer examination of the structure of the byproducts. Two main components, along with the corresponding monoacetate, accounted for more than $90 \%$ of the starting material. They were 2,5-diacetoxy$\beta$-methyl-cinnamic acid (15) and 6-acetoxy-4-methylchromen-2-one (17) from DHAP (3), as well as the corresponding compounds 2,6-diacetoxy- $\beta$-methylhydroxycinnamic acid (16) and 5-acetoxy-4-methylchromen-2-one (18) from the DHAP-isomer 10 (see Fig. 6 for the reaction mechanisms).

The cinnamic acids are the product of a Perkin reaction (Edwards et al. 2014; Pawar et al. 2011; Kurtev and Kratchanov 1969) of the acetophenone, which is an aldol-type reaction with acetic anhydride as the methylene-active component. The chromenones 
Table 1 Attempts at bisacetylation of dihydroxyacetophenones $\mathbf{3}$ and 10. Variation of reaction conditions and products obtained

\begin{tabular}{|c|c|c|c|c|}
\hline Starting material and conditions & Mono-acetate $(\%)$ & Di-acetate & $\begin{array}{l}\text { Cinnamic } \\
\text { deriv. }(\%)\end{array}$ & Chromenone $(\%)$ \\
\hline 3, $\mathrm{Ac}_{2} \mathrm{O} /$ py, r.t., $2 \mathrm{~h}$ & 82 & Trace & 3 & 8 \\
\hline 10, $\mathrm{Ac}_{2} \mathrm{O} /$ py, r.t., $2 \mathrm{~h}$ & 74 & Trace & 2 & 5 \\
\hline 3, $\mathrm{Ac}_{2} \mathrm{O} /$ py, r.t., 3 days & 72 & Trace & 3 & 11 \\
\hline 10, $\mathrm{Ac}_{2} \mathrm{O} /$ py, r.t., 3 days & 70 & Trace & 8 & 13 \\
\hline 3, $\mathrm{Ac}_{2} \mathrm{O} / \mathrm{py}, 80^{\circ} \mathrm{C}, 2 \mathrm{~h}$ & 55 & - & 13 & 22 \\
\hline 10, $\mathrm{Ac}_{2} \mathrm{O} / \mathrm{py}, 80^{\circ} \mathrm{C}, 2 \mathrm{~h}$ & 58 & - & 16 & 22 \\
\hline 3, $\mathrm{Ac}_{2} \mathrm{O} / \mathrm{DMAP}, 80^{\circ} \mathrm{C}, 2 \mathrm{~h}$ & 35 & - & 23 & 32 \\
\hline 10, $\mathrm{Ac}_{2} \mathrm{O} / \mathrm{DMAP}, 80^{\circ} \mathrm{C}, 2 \mathrm{~h}$ & 38 & - & 16 & 42 \\
\hline 3, $\mathrm{Ac}_{2} \mathrm{O} / \mathrm{TEA}, 80^{\circ} \mathrm{C}, 2 \mathrm{~h}$ & 62 & Trace & 16 & 12 \\
\hline 10, $\mathrm{Ac}_{2} \mathrm{O} / \mathrm{TEA}, 80^{\circ} \mathrm{C}, 2 \mathrm{~h}$ & 55 & Trace & 26 & 8 \\
\hline 3, $\mathrm{Ac}_{2} \mathrm{O} / \mathrm{DBU}, 80^{\circ} \mathrm{C}, 2 \mathrm{~h}$ & 22 & - & 5 & 70 \\
\hline 10, $\mathrm{Ac}_{2} \mathrm{O} / \mathrm{DBU}, 80^{\circ} \mathrm{C}, 2 \mathrm{~h}$ & 17 & - & 11 & 62 \\
\hline diacetate of $\mathbf{3}, \mathrm{DBU}, 80^{\circ} \mathrm{C}, 2 \mathrm{~h}$ & 5 & - & - & 64 \\
\hline diacetate of $\mathbf{1 0}, \mathrm{DBU}, 80^{\circ} \mathrm{C}, 2 \mathrm{~h}$ & 6 & - & - & 72 \\
\hline
\end{tabular}

are formed theoretically by three possible processes: first, intramolecular cyclisation from the corresponding cis-cinnamic acids that result from the Perkin reaction as byproducts of the main trans-cinnamic acids. Given that no free cis-cinnamic acids were found, it was concluded that the cis-cinnamic acids yielded the corresponding chromenone immediately. The trans-cinnamic acids $\mathbf{1 5}$ and $\mathbf{1 6}$, once formed, could not afford the chromenone because of their "wrong" double bond configuration. Second, the chromenones came from the intermediate $\beta$-acetoxypropionic acid intermediates, which underwent cyclization and subsequent elimination to afford the conjugated and thus more stable chromenone skeleton. When the $\beta$-acetoxypropionic acid intermediates were isolated under milder conditions (r.t.) and then subjected to more drastic treatments $\left(80^{\circ} \mathrm{C}\right)$, they afforded the corresponding chromenones almost neatly. This can be seen as proof of the involvement of this formation mechanism. The third possible generation pathway started with the diacetates (12 or 14), the latter process known also as Baker-Venkataraman rearrangement (see Fig. 6) (Ameen and Snape 2015; Bowden and Chehel-Amiran 1986; Nowlan et al. 1950). Both diacetates, when treated with Lewis bases, produced the chromenones $\mathbf{1 7}$ and $\mathbf{1 8}$ in fair yields (Table 1) so that also the third formation pathway could be regarded as confirmed. Overall, the formation of the byproducts $\mathbf{1 5 - 1 8}$ was favored under more drastic conditions (higher temperature and/or longer reaction times), while the milder treatment produced the monoacetates $\mathbf{1 1}$ and 13. The targeted diacetates remained inaccessible under the classical base-catalyzed acetylation conditions, however.

The diacetate of DHAP (12) and the diacetate of 2,6-dihydroxyacetophenone (14) were best obtained by esterification with glacial acetic acid, catalyzed by $1 \%$ trimethylsilyl chloride (TMS-Cl), see Fig. 7. The trimethylsilyl chloride released $\mathrm{HCl}$ which in turn acted as the actual catalyst. The same effect was obtained with $\mathrm{HCl}$ in $\mathrm{MeOH}$; however, this was more difficult to dose and consumed some of the acetic acid by esterification with the methanol. Sulfuric acid, frequently used as an esterification catalyst, produced rather high amounts (approximately 10\%) of the chromenone byproducts (17 and 18); thus, it was inferior. These byproducts were completely avoided by the use of TMS-Cl. When this catalyst is employed, care must be taken that the used acetic acid is free of water; otherwise the conversion of the starting acetophenones $\mathbf{3}$ and $\mathbf{1 0}$ is rather sluggish.

Reactions of DHBQ in the presence of primary and secondary amines

The resonance structures of the dianion of DHBQ (1) indicate that the two methine positions (C-3 and C-6) 


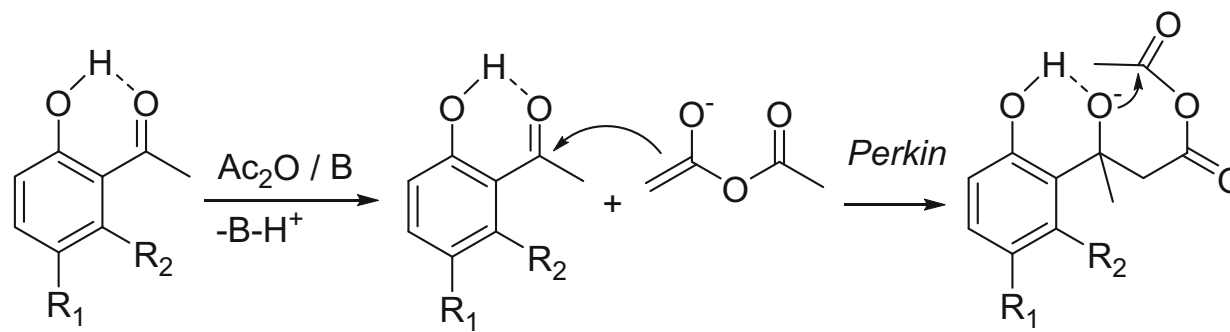

$3 \mathrm{R}_{1}=\mathrm{OH}, \mathrm{R}_{2}=\mathrm{H}$

auxiliary base

$10 \mathrm{R}_{1}=\mathrm{H}, \mathrm{R}_{2}=\mathrm{OH}$<smiles>[R]c1ccc(O)c(C(C)(CC(=O)[O-])OC(C)=O)c1[R]</smiles><smiles>[R]c1ccc2c(c1[R2])C(C)(OC(C)=O)CC([O-])(O)O2</smiles>

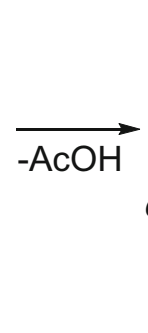

-AcO-<smiles>[R7]c1ccc(O)c(CC([2H])=CC(=O)[O-])c1[R2]</smiles><smiles>[R][CH][C@H](C)O</smiles><smiles>CCC</smiles><smiles>[R]c1ccc(OC(C)=O)c(/C(C)=C/C(=O)[O-])c1[R2]</smiles>

$15 \mathrm{R}_{1}=\mathrm{OAc}, \mathrm{R}_{2}=\mathrm{H}$

$16 \mathrm{R}_{1}=\mathrm{H}, \mathrm{R}_{2}=\mathrm{OAC}$

Fig. 6 Attempted peracetylation of DHAP (3) and its isomer 10 with $\mathrm{Ac}_{2} \mathrm{O}$ and base catalysts under more drastic conditions $\left(\mathrm{T}=80{ }^{\circ} \mathrm{C}\right)$, leading mainly to cinnamic acid and chromenone products $(\mathbf{1 5}, \mathbf{1 7}$ and 16, 18, respectively)

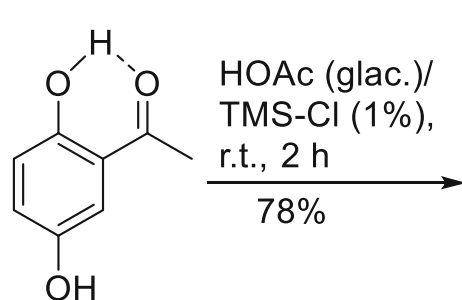

3<smiles>CC(=O)Oc1ccc(OC(C)=O)c(C(C)=O)c1</smiles>

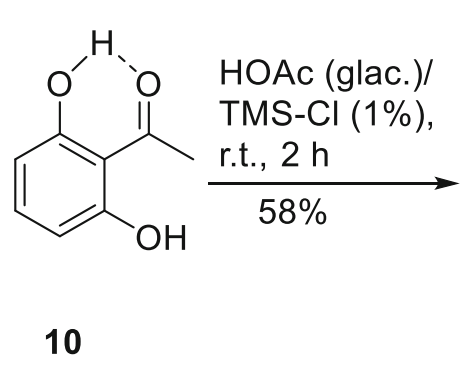<smiles>CC(=O)Oc1cccc(OC(C)=O)c1C(C)=O</smiles>

Fig. 7 Successful bisacetylation of DHAP (3) and its isomer 10. Glacial acetic acid (water-free) is both the reagent and the solvent

have negative partial charges; therefore, a reasonably high reactivity as methylene-active component, formally as dienolate of cyclohexane-1,2,4,5-tetraone, could be expected. Specifically, aldol-type or Knoevenagel-type reactions would then open the way to 3,6-disubstituted DHBQ-derivatives which are interesting not only as chromophores, but also as synthons for certain natural products. Such aldolprocesses are often catalyzed by bases, typically morpholine or piperidine.

The attempt to produce similar reactions made us aware that DHBQ reacted immediately with secondary amines to the corresponding 2,5-diaminobenzo-[1,4]-quinone derivatives (Fig. 8). 
<smiles>CC(O)C1COCCN1C1COCCN1C1=CC(=O)C(n2ccnc2)=CC1=O</smiles>

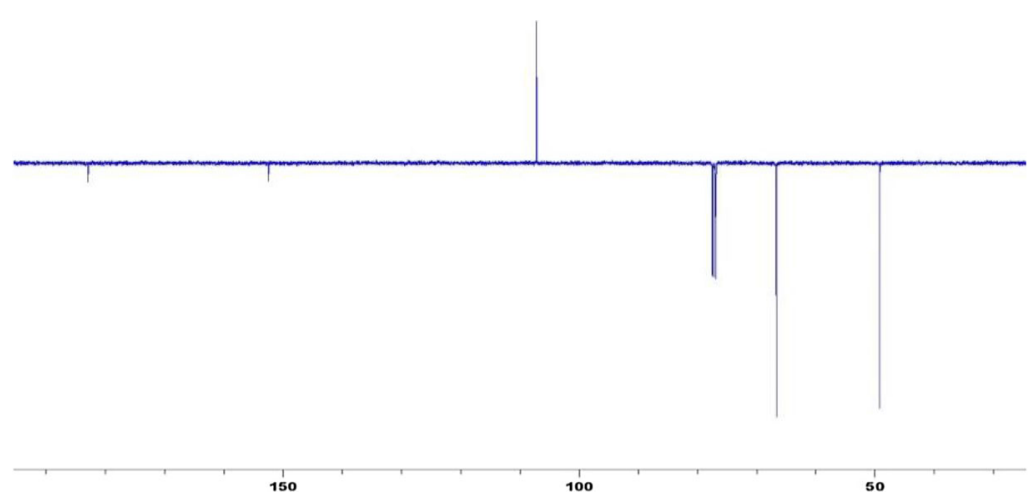

Fig. 8 Reaction of DHBQ (1) with secondary amines, prohibiting the use of such amines as basic catalysts in the presence of DHBQ. Bottom: ${ }^{13} \mathrm{C}$ NMR spectrum of 2,5-bis(1-morpholino)-benzo-[1,4]-quinone (19)

Reaction with equivalent amounts of morpholine under ambient conditions provided quantitative yields of 2,5-bis(1-morpholino)-benzo-[1,4]-quinone (19), (see Fig. 8). The same compound is often a byproduct from cellulosic materials obtained under Lyocell conditions, i.e. from celluloses regenerated from the solvent $\quad \mathrm{N}$-methylmorpholine- $\mathrm{N}$-oxide (NMMO). Morpholine is one of the main degradation products of NMMO, which immediately reacts with DHBQ to form aminobenzoquinone 19 (Rosenau et al. 1999). When DHBQ reactions are carried out in imidazolium-based ionic liquids that have not been especially purified, 2,5-bis(1-imidazolyl)-benzo-[1,4]quinone (20) is readily formed as a common byproduct. It is generated from imidazole which is present in most imidazolium-based ionic liquids as a (thermal) degradation product (Liebner et al. 2010).

A similar reaction was observed with $N, N$-dimethylacetamide (DMAc), the main component of the cellulose solvent $\mathrm{DMAc} / \mathrm{LiCl}$ : traces of dimethylamine which are ubiquitous in DMAc (Potthast et al. 2002; Rosenau et al. 2001) will immediately react with DHBQ to form the corresponding 2,5bis(dimethylamino) derivative.

The reaction with primary amines also yielded the corresponding 2,5-diaminobenzo-[1,4]-quinones as primary substitution products, but these intermediates represented secondary amines themselves which can be added to non-reacted DHBQ. The final outcome of the reaction are black, intractable condensation products. Therefore, primary and secondary amines, such as those often used as catalysts for Knoevenagel-type reactions, should not be used in combination with DHBQ. The DHBQ consumes the small amounts of added amine catalyst, and no further reaction is observed. DHBQ does not usually react with tertiary amines. For the special case of aromatic amines, such as pyridine, see above the section of the first example (Fig. 4).

It should be noted that similar reactions occur when DHBQ is mixed with enzymes or proteins, which offer many amine functionalities. This was observed in the attempts to use the laccase-mediator system (Luo et al. 2015; Widsten and Kandelbauer 2008) to bleach (decolorize) DHBQ or to convert it into insoluble polymers (Potthast et al. 1999; Kudanga et al. 2011). The characteristic color change of the transition from DHBQ to the 2,5-diamino-[1,4]-benzoquinone system was observed when the enzyme was added to a dilute solution of DHBQ. Dialysis showed that the DHBQ was covalently bound to the protein. This was confirmed by precipitation of the laccase as cross- 
linked enzyme crystals (laccase-CLECs) (Patel et al. 2009; Fernández-Fernández et al. 2013) which appeared to be stained with the color being permanent and not diminishable by washing or dialysis. This immediate addition reaction of DHBQ with primary as well as secondary amines needs to be considered in all attempts to apply enzymes in the presence of this key chromophore.

Attempted formation of bisulfite addition products of DHAP

DHAP (3) is readily soluble in an alkaline medium (see Fig. 1) but hardly soluble in neutral and acidic aqueous media. To keep DHAP dissolved under such conditions or to wash it away when it is adsorbed on cellulosic pulp, the formation of bisulfite addition products seemed to be a logical option. Usually, bisulfite addition products of acetophenones are readily formed, having good solution properties and stabilities in water over broad $\mathrm{pH}$ ranges.

The attempt to treat DHAP (3) with sodium bisulfite yielded surprising results. The expected addition process did not occur, instead a rather complex mixture of at least four components was formed, with the corresponding substituted secondary benzyl alcohol, 1,4-dihydroxy-2-(1-hydroxyethyl)-benzene (1hydroxyethyl)-hydroquinone, 21) as the main component (92\%), see Fig. 9. Compound $\mathbf{2 1}$ is the formal product of the two-electron reduction of the ethanone (acetyl) functionality. This result was surprising insofar as sulfite (oxidized to sulfate in this process) was far too weak a reductant to convert ketones into the corresponding secondary alcohols. This would usually require hydride transfer reactants, such as sodium borohydride or even the stronger lithium aluminum hydride. Isolating $\mathbf{2 1}$ as a neat compound was challenging because separating it from the accompanying byproducts was difficult, probably because of quinhydrone formation, i.e. quite stable 1:1 complexes of quinone and corresponding hydroquinone.

The key to understanding this peculiar reactivity lies in the canonic structure and tautomeric orthoquinoid form of DHAP already indicated in Fig. 1. In this ortho-quinone, the 1-hydroxyethyl moiety, the reduced acetyl functionality, is quasi pre-formed. Thus, the sulfite has only to reduce the quinone into an aromatic system but not the ethanone to the alcohol, and this is relatively easy. This also explains why other rather mild reductants, such as sodium dithionite, sodium thiosulfate and even sodium ascorbate, can reduce DHAP (3) to benzyl alcohol 21. The concentration of the ortho-quinoid tautomer/intermediate was too low for direct observation by NMR, but it appeared to be sufficient to allow the reaction to proceed in a clean and unambiguous manner. The easy formation of the quinoid tautomer can also be explained by the theory of strain-induced bond localization (SIBL) (Rosenau et al. 2005c), which predicts that the geometry of the six-membered ring system with the stable hydrogen bond can be better accommodated by a quinoid rather than an aromatic skeleton.

It should be noted that the reverse conclusion, that benzyl alcohol $\mathbf{2 1}$ could easily be oxidized back into acetophenone DHAP, is not valid. If being exposed to oxidants, the labile, oxidation-prone hydroquinone moiety of $\mathbf{2 1}$ would be affected before the (1hydroxyethyl)-substituent is oxidized to an acetyl residue. There are indications by ${ }^{1} \mathrm{H}$ NMR that 2-(1hydroxyethyl-[1,4]-benzoquinone is at least one major product of this oxidation process, but the byproducts were so many and the reaction mixture so complex that the reaction seemed to be of very little synthetic value; therefore, it was not examined further.

Reaction of DHAP under conditions of Lewis acid catalysis

DHAP (3) (and its OH-isomer 10) are interesting compounds for reactivity studies, because of the inherent "struggle" among their substituents which exert both activating (hydroxyl, $\mathrm{OH}$ ) and deactivating (acetyl, $\mathrm{CH}_{3} \mathrm{CO}$ ) effects on the aromatic system with regard to introduction of another substituent. Under the classic Friedel-Crafts alkylation or acylation conditions that employ Lewis acid catalysts, the electrophilic aromatic substitution reactions were accompanied by an unexpected side reaction, the deacylation (deacetylation) at position 2 of the aromatic system. Two facts about this process were particularly noteworthy: first, the cleaved-off acetyl group was not lost, but was selectively transferred to the neighboring phenolic oxygen so that hydroquinone monoacetate (22) was the only byproduct. The process was thus a reverse Fries rearrangement (Blatt 1940; Martin 1992) (see Fig. 10). Free hydroquinone, the 
<smiles></smiles>

DHAP (3)<smiles>C=C=CC=c1ccc(O)cc1=C(C)C</smiles>

ortho-quinoid tautomer<smiles>CC(O)c1cc(O)ccc1O</smiles>

21

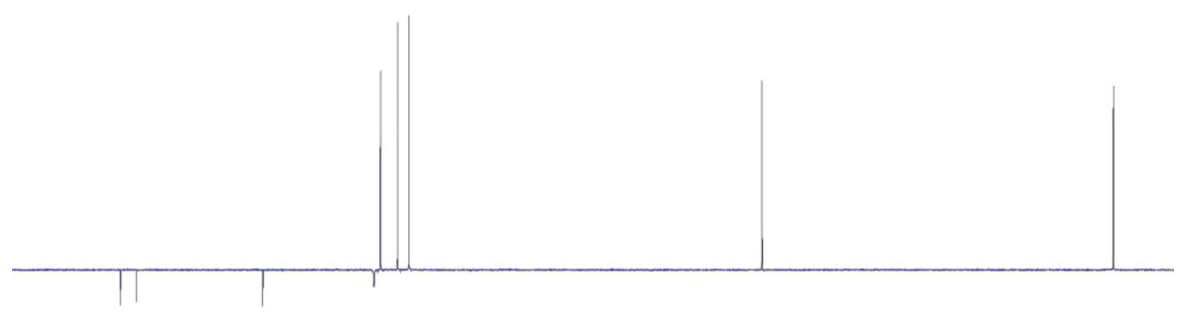

160

140

120

100

Fig. 9 Unexpected reduction of DHAP (3) to the corresponding benzyl alcohol $\mathbf{2 1}$ by mild reductants in aqueous media, proceeding via ortho-quinoid tautomeric intermediates. Bottom:
${ }^{13} \mathrm{C}$ NMR spectrum of benzyl alcohol 21 (the resonance at 118.5 ppm belongs to an unknown impurity)

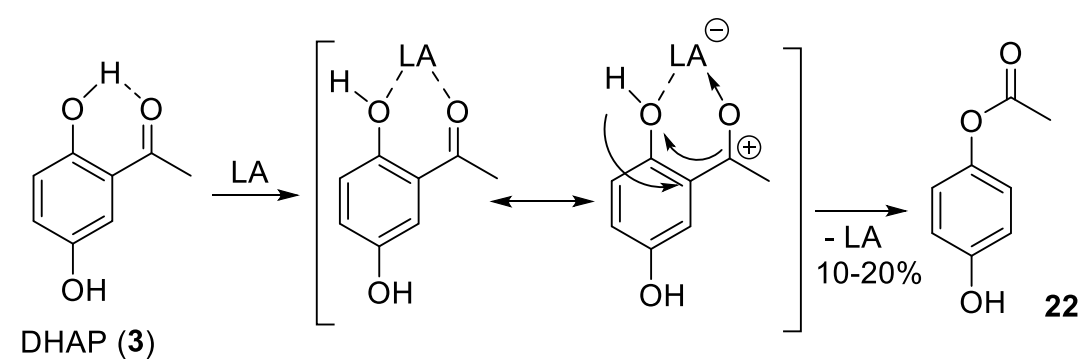
DHAP (3)
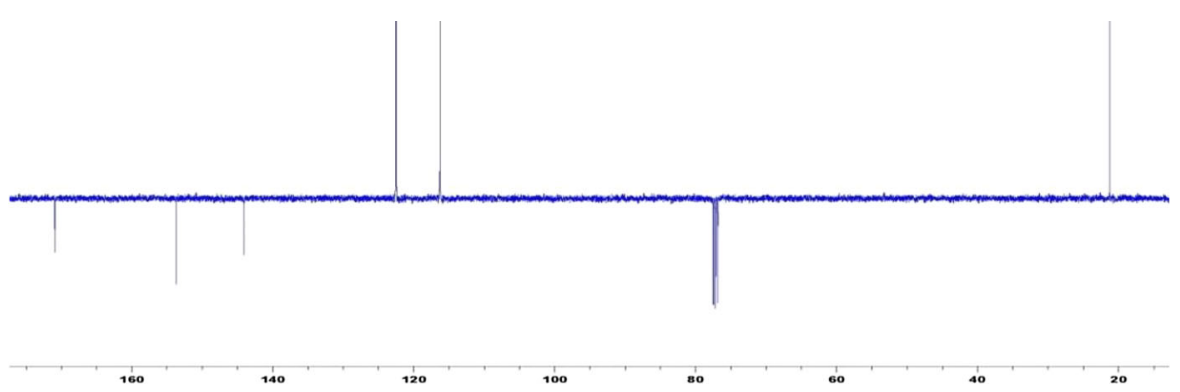

Fig. 10 Inverse Fries rearrangement as a common side reaction of the treatment of DHAP (3) with Lewis acids $\left(\mathrm{AlCl}_{3}\right.$, $\mathrm{BF}_{3} \cdot \mathrm{Et}_{2} \mathrm{O}, \mathrm{SnCl}_{4}$ in either catalytic or stoichiometric amounts)

product of simple deacylation without [1,3]-acyl shift, was obtained only in traces that likely resulted from a de-esterification of the already formed $\mathbf{2 2}$ rather than leading to hydroquinone monoacetate (22) as the main component of a rather complex product mixture. Bottom: ${ }^{13} \mathrm{C}$ NMR spectrum of pure 22

the formation of hydroquinone from the beginning. Second, the deacylation process seemed to be almost inevitable. It occurred at relatively constant yields of 
10-20\%, irrespective of the type and concentration of Lewis acid used, with $\mathrm{AlCl}_{3}, \mathrm{BF}_{3} \cdot \mathrm{Et}_{2} \mathrm{O}$, and $\mathrm{SnCl}_{4}$ having been tested in $0.01,0.05,0.1,0.5,1.0$ and 2 molar equivalents.

While Fries rearrangements are usually conducted in the presence of equimolar (and higher) amounts of Lewis acid, the reverse Fries process from DHAP already proceeded in the presence of only $1 \%$ of Lewis acid catalyst. In addition, the product ketones from a Fries rearrangement are usually considered to be thermodynamically more stable than the starting phenyl esters because of the double interaction of the Lewis acid with both the acyl oxygen and the neighboring hydroxyl oxygen. At present, we cannot answer the question why DHAP is an exception to this rule, and why the yields of the rearrangement product 22 lie in the same range so consistently, which defied the attempts to avoid or to enforce its formation. Even though aspects of its mechanism are not yet understood, this side reaction of DHAP should be considered when a Lewis acid-catalyzed alkylation or acylation process of this cellulosic key chromophore is planned as a step in a synthetic sequence.

Reaction behavior of DHBQ with chlorinating agents

It seemed reasonable to assume that the reaction of DHBQ (1) with chlorinating agents would produce chloranilic acid (2,5-dihydroxy-3,6-dichloro-[1,4]benzoquinone, $\mathbf{2 3}$ ), a well-known derivative involved in the chemistry of the common oxidant chloranil (2,3,5,6-tetrachloro-[1,4]-benzoquinone, 24). The negative partial charge at C-3 and C-6 of DHBQ (cf. the resonance structure in Fig. 1) made a selective reaction with $\mathrm{Cl}^{+}$-donating agents likely. The conversion into chloranilic acid would be a way to easily convert DHBQ into a chemical for which known analytical approaches exist.

Satisfyingly, the reaction with hypochlorite, $\mathrm{N}$ chlorosuccinimide and cyanuric chloride produced only one main product in excellent yields, but the analytical data gave rise to doubts about its structure. While in neutral medium the compound exhibited three ${ }^{13} \mathrm{C}$ NMR resonances-the same number as was expected for chloranilic acid, the chemical shifts seemed to deviate rather strongly from expectations. When the product gave only one ${ }^{13} \mathrm{C}$ resonance in alkaline aqueous solution, the assumption that the product was chloranilic acid had to be given up. Further structure elucidation proved the reaction product to be rhodizonic acid (5,6-dihydroxycyclohex-5-ene-1,2,3,4-tetrone, 25), which in acidic and neutral aqueous media is present as the bis(keto hydrate), 2,3,5,5,6,6-hexahydroxycyclohex-2-ene1,4-dione (26), cf. the characteristic ketohydrate ${ }^{13} \mathrm{C}$ NMR resonance at $94 \mathrm{ppm}$ (see Fig. 11, bottom left). In alkaline media, it forms a symmetric, aromatic rhodizonate dianion (26a) which produces a single ${ }^{13} \mathrm{C}$ NMR signal (see Fig. 11, bottom right).

The intermediacy of chloroanilic acid in the formation of rhodizonate was excluded because chloranilic acid, when applied as the starting material, did not form any rhodizonic acid/rhodizonate under the used conditions. The latter was thus a genuine reaction product of the DHBQ "chlorination". Analogous to the bleaching chemistry of the cellulosic key chromophores with chlorine dioxide (D stage bleaching) (Hosoya et al. 2018), radical processes, in particular a single-electron transfer from the electron rich DHBQdianion to the electron-deficient chlorine cation, are likely involved as initial steps, which are followed by the reaction of the resulting DHBQ radical species with excess water to eventually form rhodizonic acid.

Apart from the unexpected outcome, the reactions of DHBQ with hypochlorite or chlorine dioxide are noteworthy also from another, more practical aspect: the chromophore DHBQ was converted into an even more potent and more stable chromophore by bleaching agents, namely rhodizonic acid/rhodizonate (26/ 26a). The chromophoric effect was especially pronounced in the presence of transition metal ions, many of which form rhodizonate complexes with extremely high extinction coefficients. Iron, copper, and manganese ions are especially important in the pulp bleaching context (Hettegger et al. 2016). It is a little known, but intriguing fact that rhodizonic acid has been used in criminalistics for more than one century for detecting gunshot residues on the hands and clothing by the extremely sensitive detection of lead traces as respective rhodizonate complexes.

Attempted methylation of DHNQ with diazomethane

The cellulosic key chromophore DHNQ (2) is a compound that is stabilized by extensive resonance (see Fig. 1). In neutral and alkaline media, a dianion in 


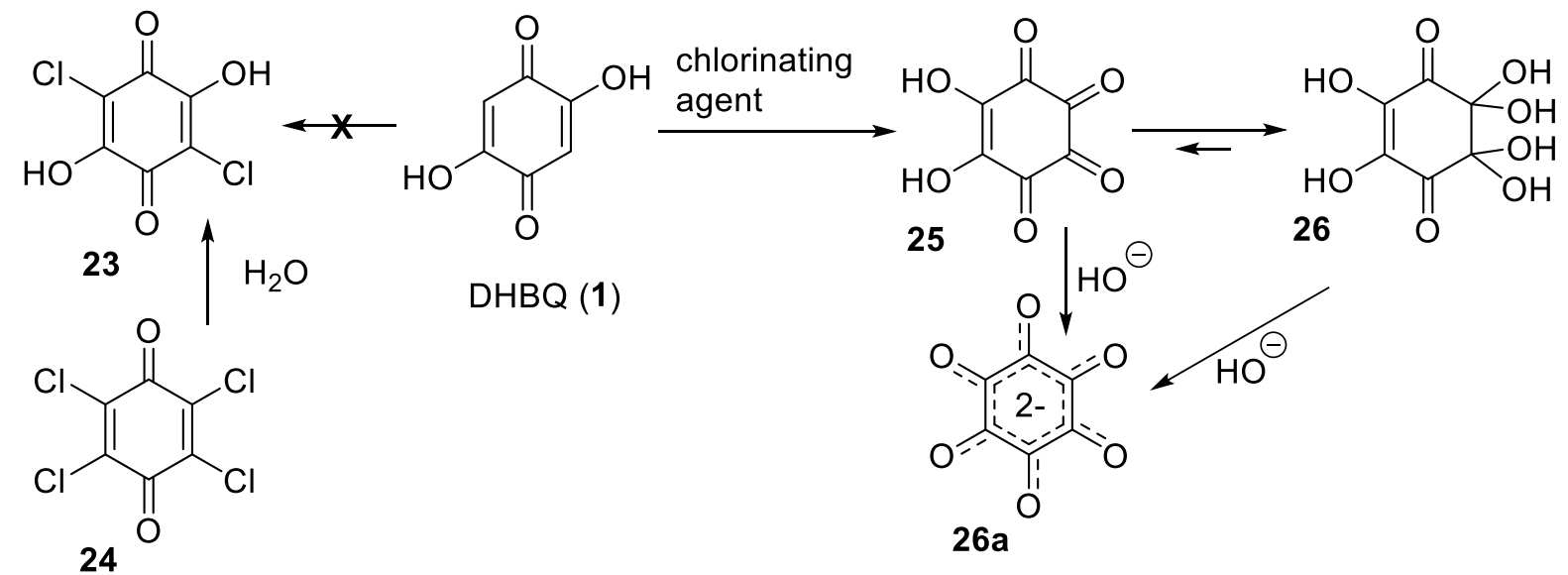

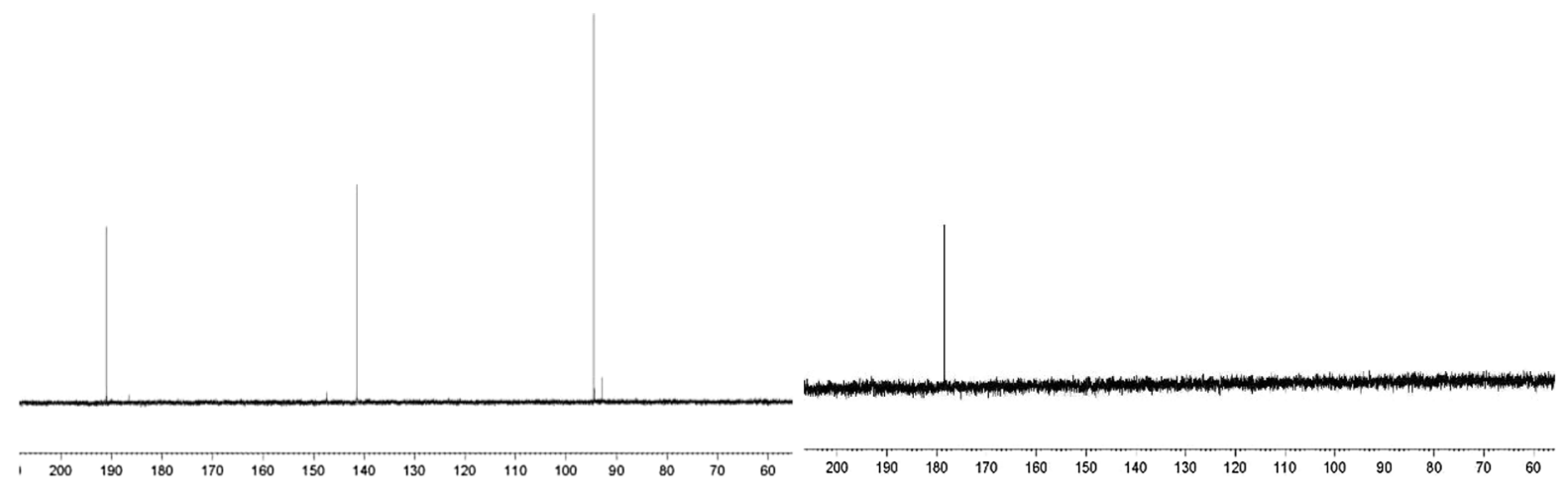

Fig. 11 Reaction of DHBQ (1) with $\mathrm{Cl}^{+}$-donating reagents producing rhodizonic acid (26) rather than the expected chloranilic acid (23). Bottom: ${ }^{13} \mathrm{C}$ NMR spectra of rhodizonic

which aromatic and quinoid "half" become indistinguishable is formed. Methylation of the two phenolic hydroxyl groups in the aromatic part would be a suitable means to "anchor" the two parts by localizing the double bonds, thus canceling the resonance stabilization. However, methylation by methyl halides after deprotonation was not possible because the deprotonation causes the immediate formation of the dianion with its strongly delocalized double bonds. Therefore, we attempted methylation under nonalkaline/non-basic conditions, and the reaction with diazomethane seemed to be the best method.

Although the reaction with diazomethane (DAM) proceeded promptly and provided a single product (Fig. 12), this compound was not the expected 5,8dimethoxy-[1,4]-naphthoquinone (27). It was the heterocycle 5,8-dihydroxy-1H-benzo[f]indazole-4,9dion (29), which had evidently been formed by a [1,3]-dipolar cycloaddition $([3+2]$-cycloaddition of acid (left, in $\mathrm{D}_{2} \mathrm{O} / \mathrm{DCl}, \mathrm{pH}=2$ ) and the symmetric, aromatic rhodizonate dianion (26a) (right, $\mathrm{D}_{2} \mathrm{O} / \mathrm{NaOD}, \mathrm{pH}=10$ )

diazomethane (Houk and Luskus 1970; Muray et al. 2000)) to the quinoid C2-C3-double bond in DHNQ, followed by oxidation of the primary intermediate $\mathbf{2 8}$. In an inert atmosphere, the slightly yellow intermediate $\mathbf{2 8}$ was initially obtained, but was fast and quantitatively oxidized to the dark red indazoledione $\mathbf{2 9}$ as soon as came in contact with air. Interestingly, this air oxidation regioselectively affects only the central hydroquinone rather than the lateral motif in the heterocycle; thus the hypothetical isomer $\mathbf{3 0}$ was not observed. This outcome can once again be explained by the SIBL theory (strain-induced bond localization) (Rosenau et al. 2005c). The pyrazole ring can be better accommodated when anellated to a benzoquinone rather than to an aromatic hydroquinone system.

It would appear that the $[3+2]$-cycloaddition of diazomethane is quite favored with DHNQ as the coreactant. This was concluded from the absence of any 
Fig. 12 Reaction of DHNQ (2) with diazomethane produced the heterocycle 5,8-dihydroxy- $1 \mathrm{H}$ benzo[f]indazole-4,9-dion (29) rather than the expected bismethylation product 27. Bottom: X-ray crystal structure of product $\mathbf{2 9}$ based on the $40 \%$ thermal ellipsoids with an overlay of the graphic representation of the lowest unoccupied molecular orbital (LUMO), computed on the basis of the $\mathrm{X}$-ray structure geometry at the DFT (B3LYP/6-31G*) level of theory

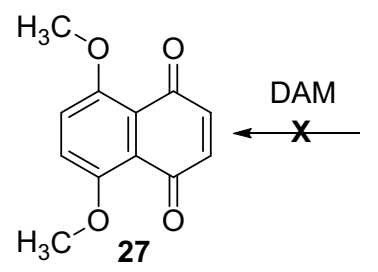<smiles>O=C1C=CC(=O)c2c(O)ccc(O)c21</smiles><smiles>[Mg][Mg]</smiles><smiles>O=C1c2c(O)ccc(O)c2C(=O)C2NN=CC12</smiles>

DAM: diazomethane<smiles>C=[N+]=[N-]</smiles><smiles>Oc1ccc(O)c2c(O)c3[nH]ncc3c(O)c12</smiles>
28<smiles>C[Z17](C)(C)CC1C=CC(=O)c2c1c(O)c1cn[nH]c1c2O</smiles>

30

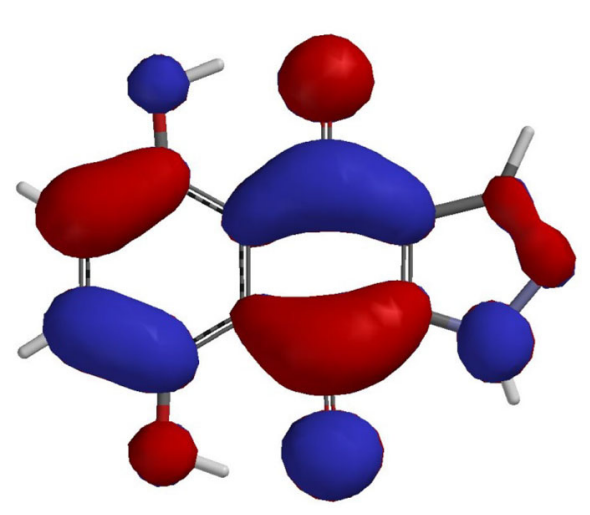

byproducts, in particular the intended methylation product 27. As satisfying as the neatness of this reaction might be from the viewpoint of its applicability to synthesis, all of the attempts to convert DHNQ (2) into its bis(methyl ether) derivative have unfortunately failed thus far.

\section{Conclusion}

The chemistry of yellowing and bleaching of cellulose has important economic implications. This is more than evident from the fact that a large aspect of the pulp and paper industry, a mainstay of many national economies worldwide, is concerned with cellulose chromophore destruction, i.e., cellulose bleaching. There is a great diversity in the number of bleaching sequences and conditions that are used in this industry. For cellulose researchers, it is the scientific challenge of tricky analyses and surprising chemical behavior that makes cellulosic chromophores an attractive area of exploration. The low chromophore concentration in pulps is a distinct difficulty, and the special molecular features-high stability through resonance or other kinds of stabilization - put the study of the chemical behavior of chromophores outside mainstream chemistry. This special stability of the cellulosic key chromophores accounts for their increased resistance to bleaching agents and their resulting ability to survive bleaching attempts much longer than most other-usually much less stable-chromophores. In addition, it is the reason for some of the unexpected chemistry regarding their derivatization and chemical modification. For the organic chemist, the eight examples of their chemistry presented in this account offer outcomes that, at first glance, might seem counter-intuitive; however, most can be easily explained when the special stabilization of key chromophores is taken into account.

It is hoped that the aspects of cellulosic chromophore chemistry presented here are instructive and informative. The goal is to help other researchers to avoid the pitfalls and failures in chromophore chemistry encountered in the authors' previous work. In 
sum, these examples show how challenging and sometimes tedious, but also educational and rewarding, the work with cellulosic chromophores can be.

\section{Materials and Methods}

Commercial chemicals were of the highest grade available and were used without further purification. Reagent-grade solvents were used for all of the extractions and workup procedures. Distilled water was used for all of the aqueous solutions.

NMR spectra of dry samples were recorded on a Bruker Avance II 400 instrument (Rheinstetten, Germany) with a resonance frequency of $400.13 \mathrm{MHz}$ for ${ }^{1} \mathrm{H}$ and $100.62 \mathrm{MHz}$ for ${ }^{13} \mathrm{C}$. The samples were dissolved in perdeuterated solvents chloroform, DMSO or pyridine $(99.8 \%$ D, Euriso-top, Saint-Aubin, France). Raw data processing was carried out with ACD/NMR Processor Academic Edition. Signal assignment was accomplished using attached proton test (APT) and 2D NMR techniques (COSY, HSQC and HMBC) (Bennett et al. 1995). The chemical shift values are given in $\delta \mathrm{ppm}$ values relative to TMS, coupling constants are given in $\mathrm{Hz}$.

FTIR experiments were performed on a PerkinElmer Frontier IR Single-Range spectrometer (Waltham, Massachusetts, USA) in ATR mode (diamond/ $\mathrm{ZnSe}$ crystal, $\mathrm{LiTaO}_{3}$ detector, $\mathrm{KBr}$ windows). Elemental analyses were done on a EURO EA 3000 CHNS-O instrument from HEKAtech (Wegberg, Germany) at the Microanalytical Laboratory of Vienna University. Halide contents $(\mathrm{Cl})$ were determined by argentometry.

TLC was performed on Silica gel 60 F254 precoated glass plates (Merck). Flash column chromatography was performed on Silica gel 60 from Merck (Darmstadt, Germany). Solvents were purchased in synthesis grade from Roth, Sigma-Aldrich and VWR and were used as received. Reagents were obtained from Sigma-Aldrich, TCI and Fluka. Melting points were determined on a Kofler hot stage with a ReichertBiovar microscope microscope and are uncorrected.

X-ray data collection was performed with a Bruker AXS Smart APEX CCD diffractometer and graphite monochromatized Mo-K $\alpha$ radiation; corrections for absorption with the program SADABS, structure solution with direct methods, structure refinement on $F^{2}$ (Bruker AXS, 2001: programs SMART, version
5.626; SAINT, version 6.36A; SADABS version 2.05; XPREP, version 6.12; SHELXTL, version 6.10. Bruker AXS Inc., Madison, WI, USA).

The supplementary crystallographic data for this paper can be obtained free of charge via www.ccdc. cam.ac.uk/data_re-quest/cif, by emailing data_request@ccdc.cam.ac.uk, or by contacting The Cambridge Crystallographic Data Centre, 12, Union Road, Cambridge CB2 1EZ, UK; fax: +44 1223336033.

2,5-Diacetoxy-[1,4]-benzoquinone (4). 2,5-Dihydroxy-[1,4]-benzoquinone (1, $3.57 \mathrm{mmol}, 500 \mathrm{mg})$ was dissolved in glacial acetic acid $(10 \mathrm{~mL})$ and concentrated sulfuric acid $(0.05 \mathrm{~mL})$ was added. The mixture was stirred at room temperature for $3 \mathrm{~min}$, neutralized by a saturated aqueous $\mathrm{NaHCO}_{3}$ solution and extracted with $\mathrm{CH}_{2} \mathrm{Cl}_{2}$. Upon evaporation of the solvent, a crystalline residue appeared which was recrystallized from glacial acetic acid to provide compound 4 in $85 \%$ yield $(680 \mathrm{mg})$ as colorless plates. ${ }^{1} \mathrm{H} \mathrm{NMR}\left(\mathrm{CDCl}_{3}\right): \delta=2.08\left(\mathrm{~s}, 6 \mathrm{H}, 2 \times \mathrm{CH}_{3}\right.$, $\mathrm{OAc}), 6.16 \mathrm{ppm}(\mathrm{s}, 2 \mathrm{H}, \mathrm{H}-3, \mathrm{H}-6) .{ }^{13} \mathrm{C} \mathrm{NMR}\left(\mathrm{CDCl}_{3}\right)$ : $\delta=20.12\left(2 \times \mathrm{CH}_{3}, \mathrm{OAc}\right), 122.5(\mathrm{C}-3, \mathrm{C}-6), 148.4$ (C-2, C-5.), $167.5(2 \times \mathrm{C}=\mathrm{O}, \quad \mathrm{OAc}), 175.8 \mathrm{ppm}$ $(2 \times \mathrm{C}=\mathrm{O}, \mathrm{C}-1, \mathrm{C}-4)$.

3-(4-Pyridyl)-1,2,4,5-benzenetetrol tetraacetate (5). 2,5-Dihydroxy-[1,4]-benzoquinone (1, $3.57 \mathrm{mmol}, 500 \mathrm{mg}$ ) was dissolved in pyridine (36 mmol, $2.88 \mathrm{~mL}$ ) and stirred at room temperature under argon for $1 \mathrm{~h}$. Acetic anhydride $(17 \mathrm{mmol}$, $1.7 \mathrm{~mL}$ ) was added. The reaction mixture was stirred under reflux for $2 \mathrm{~h}$ and at room temperature for $27 \mathrm{~h}$ under argon atmosphere, neutralized by a saturated aqueous $\mathrm{NaHCO}_{3}$ solution and extracted with $\mathrm{CH}_{2} \mathrm{Cl}_{2}$. The residue was purified by column chromatography $\left(\mathrm{CH}_{2} \mathrm{Cl}_{2} / n\right.$-hexane, v/v $\left.=1: 1,+5 \% \mathrm{MeOH}\right)$ to yield 5 in $68 \%$ yield $(940 \mathrm{mg}$ ). The compound was purified by recrystallization from DMF. ${ }^{1} \mathrm{H}$ NMR $\left(\mathrm{CDCl}_{3}\right)$ : $\delta=2.0\left(\mathrm{~s}, 6 \mathrm{H}, 2 \times \mathrm{CH}_{3}, \mathrm{OAc}\right), 2.27\left(\mathrm{~s}, 6 \mathrm{H}, 2 \times \mathrm{CH}_{3}\right.$, OAc), 7.20-7.73 (m, 2H, H-3, H-5, py), 7.28 (s, 1H, $\left.\mathrm{H}-4^{\prime}\right), 8.64-8.66 \mathrm{ppm}$ (m, H-2, H-6, py). ${ }^{13} \mathrm{C} \mathrm{NMR}$ $\left(\mathrm{CDCl}_{3}\right): \delta=20.1\left(2 \times \mathrm{CH}_{3}, \mathrm{OAc}\right), 20.7\left(2 \times \mathrm{CH}_{3}\right.$, OAc), $118.6\left(\mathrm{C}-4^{\prime}\right), 124.4$ (C-3, C-5, py), $128.8\left(\mathrm{C}-1^{\prime}\right)$, 137.6 (C-4, py), $140.23\left(\mathrm{C}-3^{\prime}, \mathrm{C}-5^{\prime}\right), 140.64\left(\mathrm{C}-2^{\prime}\right.$, C-6'), 149.74 (C-2, C-6, py), $167.54(2 \times \mathrm{C}=\mathrm{O}, \mathrm{OAc})$, 167.65 ppm $(2 \times \mathrm{C}=\mathrm{O}, \mathrm{OAc})$.

1,2,4,5-Tetraacetoxybenzene (6). 2,5-Dihydroxy[1,4]-benzoquinone (1, $3.57 \mathrm{mmol}, 500 \mathrm{mg})$ was dissolved in glacial acetic acid $(10 \mathrm{~mL})$ and zinc powder $(2.0 \mathrm{~g})$ was added. The mixture was refluxed 
for $10 \mathrm{~min}$ and stirred at $50{ }^{\circ} \mathrm{C}$ for an additional hour. The warm mixture was filtered and the residue washed with glacial acetic acid $(5 \mathrm{~mL})$. The combined organic phases were evaporated and the residue recrystallized from $n$-heptane to afford compound $\mathbf{6}(1.06 \mathrm{~g}, 96 \%)$ as white crystals, the analytical data being identical to those provided by Crosby and Lutz (1956).

3,6-Bis(dimethyl- $\lambda^{4}$-sulfaneylidene)cyclohexane1,2,4,5-tetraone (8). Representative protocol: 2,5Dihydroxybenzoquinone $(\mathbf{1}, 1.40 \mathrm{~g}, 10 \mathrm{mmol})$ was dissolved in DMSO $(5 \mathrm{~mL})$, acetic anhydride $(20 \mathrm{~mL})$ was added, and the mixture heated under stirring to $100{ }^{\circ} \mathrm{C}$ for $1 \mathrm{~h}$. A yellow solid precipitated, which was collected by filtration after cooling to room temperature and additional stirring for $3 \mathrm{~h}$ at r.t. The solid was thoroughly washed with ethyl acetate and dried in vacuo to provide $8(1.87 \mathrm{~g}, 72 \%)$. M.p. $>300{ }^{\circ} \mathrm{C} .{ }^{1} \mathrm{H}$ NMR $\left(\mathrm{D}_{2} \mathrm{O}\right): \delta=3.08 \mathrm{ppm}(\mathrm{s}, 12 \mathrm{H}, \mathrm{Me}) .{ }^{13} \mathrm{C} \mathrm{NMR}$ $\left(\mathrm{D}_{2} \mathrm{O}\right): \delta=25.4(\mathrm{Me}), 94.4(\mathrm{C}-\mathrm{S}), 177.0 \mathrm{ppm}(\mathrm{C}-\mathrm{O})$. Anal. calcd. for $\mathrm{C}_{10} \mathrm{H}_{12} \mathrm{O}_{4} \mathrm{~S}_{2}$ (260.33): $\mathrm{C}$ 46.14, $\mathrm{H}$ 4.65, S 24.63. Found: C 46.05, H 4.72, S 24.73. Recrystallization from glacial acetic acid provided the bis(acetic acid) adduct as yellow needles, m.p. $182-184{ }^{\circ} \mathrm{C}$.

\section{3-(Dimethyl- $\lambda^{4}$-sulfaneylidene)naphthalene-} 1,2,4(3H)-trione (9). Representative protocol: Compound 9 was obtained according to the above procedure, employing 2-hydroxy-naphthoquinone (7, $1.74 \mathrm{~g}, 10 \mathrm{mmol}$ ) instead of starting compound 1 . Yield: 1.97 g, 84\%. M.p. $\left(\mathrm{H}_{2} \mathrm{O}\right)=263-265{ }^{\circ} \mathrm{C} .{ }^{1} \mathrm{H}$ NMR (DCOOD): $\delta=3.30(\mathrm{~s}, 6 \mathrm{H}, \mathrm{Me}), 7.82(\mathrm{t}, 1 \mathrm{H}$, $\left.{ }^{\mathrm{Ar}} \mathrm{H}\right), 7.92\left(\mathrm{t}, 1 \mathrm{H},{ }^{\mathrm{Ar}} \mathrm{H}\right), 8.11 \mathrm{ppm}\left(\mathrm{t}, 2 \mathrm{H},{ }^{\mathrm{Ar}} \mathrm{H}\right) .{ }^{13} \mathrm{C}$ NMR (DCOOD): $\delta=25.7(\mathrm{Me}), 98.5(\mathrm{C}-\mathrm{S}), 127.5$ (C), $128.3(\mathrm{C}), 131.3(\mathrm{CH}), 134.1(\mathrm{CH}), 134.3(\mathrm{CH})$, $136.5(\mathrm{CH}), 172.2,181.6,182.4 \mathrm{ppm}$. Anal. calcd. for $\mathrm{C}_{12} \mathrm{H}_{10} \mathrm{O}_{3} \mathrm{~S}$ (234.28): C 61.52, H 4.30, S 13.69. Found: C 61.42, H 4.33, S 13.52 .

DHAP monoacetate, 2-hydroxy-5-acetoxy-acetophenone (11). 2,5-Dihydroxyacetophenone (3, $3.29 \mathrm{mmol}, 500 \mathrm{mg}$ ) was dissolved in pyridine $(3 \mathrm{~mL})$ and stirred at room temperature under argon for $1 \mathrm{~h}$. Acetic anhydride $(3 \mathrm{~mL})$ was added. The reaction mixture was stirred at room temperature for $2 \mathrm{~h}$ under argon atmosphere, neutralized by a saturated aqueous $\mathrm{NaHCO}_{3}$ solution and extracted with $\mathrm{CH}_{2} \mathrm{Cl}_{2}$. The residue was purified by column chromatography $\left(\mathrm{CH}_{2} \mathrm{Cl}_{2} / n\right.$-heptane, v/v $\left.=1: 1,+5 \% \mathrm{MeOH}\right)$ to yield monoacetate 11 in $82 \%$ yield $(523 \mathrm{mg}$ ) as colorless needles. ${ }^{1} \mathrm{H}$ NMR $\left(\mathrm{CDCl}_{3}\right): \delta=2.21\left(\mathrm{~s}, 3 \mathrm{H}, \mathrm{CH}_{3}\right.$ in
OAc), $2.50\left(\mathrm{~s}, 3 \mathrm{H}, \mathrm{CH}_{3}\right.$ in $\left.\mathrm{Ac}\right), 6.88(\mathrm{~d}, 1 \mathrm{H}$, $\left.{ }^{3} J=9.3 \mathrm{~Hz}, \quad \mathrm{H}-3\right), 7.13 \quad\left(\mathrm{dd}, 1 \mathrm{H},{ }^{3} J=9.3 \mathrm{~Hz}\right.$, $\left.{ }^{4} J=1.6 \mathrm{~Hz}, \mathrm{H}-4\right), 7.38\left(\mathrm{~d}, 1 \mathrm{H},{ }^{4} J=1.6 \mathrm{~Hz}, \mathrm{H}-6\right)$, $12.06 \mathrm{ppm}(\mathrm{s}, 1 \mathrm{H}, \mathrm{OH}) .{ }^{13} \mathrm{C} \mathrm{NMR}\left(\mathrm{CDCl}_{3}\right): \delta=20.7$ $\left(\mathrm{CH}_{3}\right.$ in $\left.\mathrm{OAc}\right), 26.3\left(\mathrm{CH}_{3}\right.$ in $\left.\mathrm{Ac}\right), 119.0(\mathrm{CH}), 119.2$ (C), $122.7(\mathrm{CH}), 130.0(\mathrm{CH}), 142.0(\mathrm{C}), 159.8(\mathrm{C})$, 169.5 (CO in OAc), $203.6 \mathrm{ppm}$ (CO in Ac). Anal. calcd. for $\mathrm{C}_{10} \mathrm{H}_{10} \mathrm{O}_{4}$ (194.19): $\mathrm{C} 61.85, \mathrm{H}$ 5.19. Found: C 61.80, H 5.32.

2-Hydroxy-6-acetoxy-acetophenone (13) was obtained as white powder according to the same protocol in $74 \%$ yield $(472 \mathrm{mg}$ ), starting from 2,6dihydroxyacetophenone (10) $(3.29 \mathrm{mmol}, 500 \mathrm{mg})$.

DHAP diacetate, 2,5-diacetoxy-acetophenone (12). 2,5-Dihydroxyacetophenone $(3,3.29 \mathrm{mmol}, 500 \mathrm{mg})$ was dissolved in freshly distilled glacial acetic acid $(10 \mathrm{~mL})$ and trimethylsilyl chloride $(0.1 \mathrm{~mL})$ was added. The reaction mixture was stirred at room temperature for $2 \mathrm{~h}$ under argon atmosphere, neutralized by a saturated aqueous $\mathrm{NaHCO}_{3}$ solution and extracted with $\mathrm{CH}_{2} \mathrm{Cl}_{2}$. The residue formed upon evaporation of the solvent was recrystallized from glacial acetic acid to yield DHAP diacetate (12) in $78 \%$ yield $(606 \mathrm{mg})$ as colorless needles. ${ }^{1} \mathrm{H}$ NMR $\left(\mathrm{CDCl}_{3}\right): \delta=2.16\left(\mathrm{~s}, 3 \mathrm{H}, \mathrm{CH}_{3}\right.$ in $\left.\mathrm{OAc}\right), 2.20(\mathrm{~s}, 3 \mathrm{H}$, $\mathrm{CH}_{3}$ in $\mathrm{OAc}$ ), 2.46 (s, $3 \mathrm{H}, \mathrm{CH}_{3}$ in $\mathrm{Ac}$ ), $6.88(\mathrm{~d}, 1 \mathrm{H}$, $\left.{ }^{3} J=9.0 \mathrm{~Hz}, \quad \mathrm{H}-3\right), 7.16 \quad\left(\mathrm{dd}, 1 \mathrm{H},{ }^{3} J=9.0 \mathrm{~Hz}\right.$, $\left.{ }^{4} J=1.2 \mathrm{~Hz}, \mathrm{H}-4\right), 7.40\left(\mathrm{~d}, 1 \mathrm{H},{ }^{4} J=1.2 \mathrm{~Hz}, \mathrm{H}-6\right)$, $12.22 \mathrm{ppm}(\mathrm{s}, 1 \mathrm{H}, \mathrm{OH}) .{ }^{13} \mathrm{C} \mathrm{NMR}\left(\mathrm{CDCl}_{3}\right): \delta=20.4$ $\left(\mathrm{CH}_{3}\right.$ in $\left.\mathrm{OAc}\right), 20.7\left(\mathrm{CH}_{3}\right.$ in $\left.\mathrm{OAc}\right), 26.0\left(\mathrm{CH}_{3}\right.$ in $\left.\mathrm{Ac}\right)$, $119.2(\mathrm{C}), 119.6(\mathrm{CH}), 123.2(\mathrm{CH}), 130.8(\mathrm{CH}), 142.6$ (C), $159.3(\mathrm{C}), 168.3$ (CO in OAc), 169.4 (CO in $\mathrm{OAc}$ ), $182.4 \mathrm{ppm}$ (CO in $\mathrm{Ac}$ ). Anal. calcd. for $\mathrm{C}_{12} \mathrm{H}_{12} \mathrm{O}_{5}$ (236.22): C 61.02, $\mathrm{H}$ 5.12. Found: $\mathrm{C}$ 60.93, H 5.24.

2,6-Diacetoxy-acetophenone (14) was obtained as colorless plates according to the same protocol in 58\% yield (528 mg), starting from 2,6-dihydroxyacetophenone (10, $3.29 \mathrm{mmol}, 500 \mathrm{mg})$.

2,5-Di(morpholin-1-yl)-benzo-[1,4]-quinone (19). 2,5-Dihydroxy-[1,4]-benzoquinone (1, $3.57 \mathrm{mmol}$, $500 \mathrm{mg}$ ) was dissolved in acetonitrile $(10 \mathrm{~mL})$ and morpholine $(1 \mathrm{~mL})$ was added. The mixture was stirred at room temperature for $15 \mathrm{~min}$, and the solvents were evaporated. The residue was recrystallized from 1,4-dioxane to provide compound 19 in quantitative yield $(680 \mathrm{mg})$ as orange, amorphous solid. ${ }^{1} \mathrm{H}$ NMR $\left(\mathrm{CDCl}_{3}\right): \delta=3.53(\mathrm{~s}, 8 \mathrm{H}, 4 \times \mathrm{N}-$ $\left.\mathrm{CH}_{2}\right), 3.79\left(\mathrm{~s}, 8 \mathrm{H}, 4 \times \mathrm{O}-\mathrm{CH}_{2}\right), 5.53 \mathrm{ppm}(\mathrm{s}, 2 \mathrm{H}$, 
$\mathrm{CH}) .{ }^{13} \mathrm{C} \mathrm{NMR}\left(\mathrm{CDCl}_{3}\right): \delta=49.3\left(\mathrm{~N}-\mathrm{CH}_{2}\right), 66.6(\mathrm{O}-$ $\left.\mathrm{CH}_{2}\right)$, 107.2, $(\mathrm{CH}), 152.4(\mathrm{C}-\mathrm{N}), 182.9$ ppm $(\mathrm{C}=\mathrm{O})$. Anal. calcd. for $\mathrm{C}_{14} \mathrm{H}_{18} \mathrm{~N}_{2} \mathrm{O}_{4}$ (278.31): $\mathrm{C}$ 60.42, $\mathrm{H}$ 6.52, N 10.07. Found: C 60.30, H 6.64, N 9.94.

2,5-Di(1H-imidazol-1-yl)-benzo-[1,4]-quinone

(20). 2,5-Dihydroxy-[1,4]-benzoquinone (1, $3.57 \mathrm{mmol}, 500 \mathrm{mg}$ ) was dissolved in chloroform $(20 \mathrm{~mL})$ and imidazole $(2.5 \mathrm{~mL})$ was added. The mixture was stirred at room temperature for $15 \mathrm{~min}$, washed three times with water $(3 \times 5 \mathrm{~mL})$, and dried over anhydrous $\mathrm{MgSO}_{4}$. After removal of the solids by filtration, the solvent was evaporated and the residue was recrystallized from 1,4-dioxane to provide compound 20 in $92 \%$ yield $(789 \mathrm{mg}$ ) as red amorphous solid. ${ }^{1} \mathrm{H} \mathrm{NMR}\left(\mathrm{CDCl}_{3}\right): \delta=5.60(\mathrm{~s}, 2 \mathrm{H}, \mathrm{CH}), 6.84(\mathrm{~s}$, 2H, H-5'), 6.98 (s, 2H, H-4'), 7.36 ppm (s, 2H, H-2'). ${ }^{13} \mathrm{C} \mathrm{NMR}\left(\mathrm{CDCl}_{3}\right): \delta=109.5,(\mathrm{CH}), 120.4\left(\mathrm{C}-4^{\prime}\right)$, 128.7 (C-5'), 137.9 (C-2'), 154.8 (C-N), 180.8 ppm $(\mathrm{C}=\mathrm{O})$. Anal. calcd. for $\mathrm{C}_{12} \mathrm{H}_{8} \mathrm{~N}_{4} \mathrm{O}_{2}$ (240.22): $\mathrm{C}$ 60.00, H 3.36, N 23.32. Found: C 60.08, H 3.42, N 23.48.

2-(1-Hydroxyethyl)benzene-1,4-diol (21). 2,5-Dihydroxyacetophenone $(\mathbf{3}, 3.29 \mathrm{mmol}, 500 \mathrm{mg})$ was dissolved in 1,4-dioxane ( $5 \mathrm{~mL}$ ) and aqueous sodium bisulfite solution $(2 \mathrm{M}, 20 \mathrm{~mL})$ was added. The mixture was vigorously stirred at room temperature for $1 \mathrm{~h}$, and extracted with chloroform $(3 \times 20 \mathrm{~mL})$. The combined organic phases were washed with water $(5 \mathrm{~mL})$ and dried over anhydrous $\mathrm{MgSO}_{4}$. After filtration the solvent was evaporated and the residue was purified by column chromatography $\left(\mathrm{CHCl}_{3} /\right.$ $\mathrm{MeOH}, \mathrm{v} / \mathrm{v}=15: 1)$ to provide compound 21 in $92 \%$ yield $(789 \mathrm{mg})$ as a yellow solid. ${ }^{1} \mathrm{H} \mathrm{NMR}\left(\mathrm{CDCl}_{3}\right)$ : $\delta=1.38\left(\mathrm{~d}, 3 \mathrm{H}, \mathrm{CH}_{3},{ }^{3} \mathrm{~J}=6.8 \mathrm{~Hz}\right), 3.96(\mathrm{~s}, 1 \mathrm{H}, \mathrm{OH})$, $4.96\left(\mathrm{q}, 1 \mathrm{H}, \mathrm{CH}(\mathrm{OH}),{ }^{3} \mathrm{~J}=6.8 \mathrm{~Hz}\right), 6.53-6.64(\mathrm{~m}, 4 \mathrm{H}$, $\left.\mathrm{OH}, 3 \times{ }^{\mathrm{Ar}} \mathrm{H}\right), 7.47(\mathrm{~s}, 1 \mathrm{H}, \mathrm{OH}) .{ }^{13} \mathrm{C} \mathrm{NMR}\left(\mathrm{CDCl}_{3}\right)$ : $\delta=24.0\left(\mathrm{CH}_{3}\right), 68.8(\mathrm{CH}(\mathrm{OH})), 113.9(\mathrm{CH}), 115.3$ $(\mathrm{CH}), 117.4(\mathrm{CH}), 132.4(\mathrm{C}), 148.5(\mathrm{C}), 150.6 \mathrm{ppm}$ (C). Anal. calcd. for $\mathrm{C}_{8} \mathrm{H}_{10-} \mathrm{O}_{3}$ (254.17): $\mathrm{C} 62.33, \mathrm{H}$ 6.54. Found: C 62.20, H 6.72.

4-Acetoxyphenol, hydroquinone monoacetate (22). 2,5-Dihydroxyacetophenone (3, $3.29 \mathrm{mmol}, 500 \mathrm{mg})$ was dissolved in dry 1,4-dioxane $(10 \mathrm{~mL})$ and $\mathrm{BF}_{3} \cdot \mathrm{Et}_{2} \mathrm{O}$ (varying amounts, between 0.01 and 2 eq.) was added. The mixture was vigorously stirred at room temperature for $1 \mathrm{~h}$, and extracted three times with saturated aqueous $\mathrm{NaHCO}_{3}$ solution. TLC control $\left(\mathrm{CHCl}_{3} / \mathrm{MeOH}, \mathrm{v} / \mathrm{v}=15: 1\right)$ showed a product at $\mathrm{R}_{f}=0.58$. The organic phase was dried over anhydrous $\mathrm{MgSO}_{4}$. After filtration the solvent was evaporated and the residue purified by column chromatography $\left(\mathrm{CHCl}_{3} / \mathrm{MeOH}, \mathrm{v} / \mathrm{v}=15: 1\right)$ to provide hydroquinone monoacetate $(\mathbf{2 2})$ in $16 \%$ yield $(81 \mathrm{mg})$ as colorless solid. ${ }^{1} \mathrm{H} \mathrm{NMR}\left(\mathrm{CDCl}_{3}\right): \delta=2.28(\mathrm{~s}, 3 \mathrm{H}$, $\left.\mathrm{CH}_{3}\right), 5.62$ (s, br, $\left.1 \mathrm{H}, \mathrm{OH}\right), 6.72\left(\mathrm{~d}, 2 \mathrm{H},{ }^{3} \mathrm{~J}=8.8 \mathrm{~Hz}\right.$ ), $6.89 \mathrm{ppm}\left(\mathrm{d}, 2 \mathrm{H},{ }^{3} \mathrm{~J}=8.8 \mathrm{~Hz}\right) \cdot{ }^{13} \mathrm{C}$ NMR $\left(\mathrm{CDCl}_{3}\right)$ : $\delta=21.3\left(\mathrm{CH}_{3}\right), 116.2(\mathrm{CH}), 122.4(\mathrm{CH}), 144.1(\mathrm{C})$, 153.7 (C), $170.9 \mathrm{ppm}(\mathrm{C}=\mathrm{O})$. Anal. calcd. for $\mathrm{C}_{8} \mathrm{H}_{8} \mathrm{O}_{3}$ (252.15): C 63.15, H 5.30. Found: C 63.02, H 5.45.

The yield of 22 remained largely constant, between 10 and $20 \%$, also when the amount of $\mathrm{BF}_{3} \cdot \mathrm{Et}_{2} \mathrm{O}$ was varied, and was also not significantly affected by changing the Lewis acid to $\mathrm{AlCl}_{3}$ or $\mathrm{SnCl}_{4}$.

Rhodizonic acid (26)/sodium rhodizonate (26a). 2,5-Dihydroxy-[1,4]-benzoquinone (1, $3.57 \mathrm{mmol}$, $500 \mathrm{mg}$ ) was dissolved in $0.1 \mathrm{M}$ aqueous $\mathrm{NaOH}$ $(50 \mathrm{~mL})$. Aqueous sodium hypochlorite solution ( $13 \%$ active chlorine, $5 \mathrm{~mL}$ ) was added, and the mixture stirred for $10 \mathrm{~min}$ at room temperature. To destroy excess bleach, concentrated aqueous sodium thiosulfate was added until the $\mathrm{KI} /$ starch test was negative. The mixture was acidified to a $\mathrm{pH}$ of about 4 with $1 \mathrm{M} \mathrm{HCl}$, and brought to dryness by rotavaporation in vacuo at a bath temperature of $80^{\circ} \mathrm{C}$. The solid residue was triturated with isopropanol $(50 \mathrm{~mL})$ and solids were removed by filtration. Evaporation of the solvent provided a residue which was recrystallized from ethanol/water $(\mathrm{v} / \mathrm{v}=9: 1)$ to provide rhodizonic acid dihydrate (26) as yellow solid (602 mg, 82\%). ${ }^{1} \mathrm{H}$ NMR (DMSO- $\mathrm{d}_{6}$ ): no non-exchanging protons. ${ }^{13} \mathrm{C}$ NMR (DMSO-d $\left.\mathrm{d}_{6}\right): \delta=94.5\left(\mathrm{C}(\mathrm{OH})_{2}\right)$, $141.5(=\mathrm{C}(\mathrm{OH})), \quad 191.0 \mathrm{ppm} \quad(\mathrm{C}=\mathrm{O}) .{ }^{1} \mathrm{H} \quad \mathrm{NMR}$ (DMSO- $\mathrm{d}_{6} / 1 \mathrm{M} \mathrm{NaOD}$ in $\mathrm{D}_{2} \mathrm{O}$, v/v $=5: 1$ ): no nonexchanging protons. ${ }^{13} \mathrm{C}$ NMR (DMSO- $\mathrm{d}_{6} / 1 \mathrm{M} \mathrm{NaOD}$ in $\left.\mathrm{D}_{2} \mathrm{O}, \mathrm{v} / \mathrm{v}=5: 1\right): \delta=178.4 \mathrm{ppm}$. An aqueous solution of the product gives intensively colored precipitates with barium(II), lead(II) or copper(II) ions.

\section{5,8-Dihydroxy-1H-benzo[f]indazole-4,9-dione} (29). Working in an efficient fume hood at room temperature, a solution of diazomethane in $\mathrm{Et}_{2} \mathrm{O}$ freshly prepared from Diazald ${ }^{\circledR}$ was added dropwise to a solution of 2,5-dihydroxy-[1,4]-naphthoquinone $(2.63 \mathrm{mmol}, 500 \mathrm{mg})$ in freshly distilled and dried dioxane $(5 \mathrm{~mL})$ until the yellow color persisted. CAUTION: diazomethane is known to be toxic, explosive and cancerogenic! Two drops of glacial acetic acid were added and the solvents were 
evaporated. The red, waxy residue was purified by column chromatography $\left(\mathrm{CHCl}_{3} / n\right.$-heptane, $\mathrm{v} / \mathrm{v}=1: 1)$ to provide heterocycle 29 in $90 \%$ yield $(546 \mathrm{mg})$ as red rhombic plates. ${ }^{1} \mathrm{H}$ NMR $\left(\mathrm{CDCl}_{3}\right)$ : $\delta=7.23(\mathrm{~s}(\mathrm{~m}), 2 \mathrm{H}, \mathrm{CH}), 7.40(\mathrm{~s}, 1 \mathrm{H}, \mathrm{NH}), 7.88(\mathrm{~s}$, $1 \mathrm{H}, \mathrm{CH}-\mathrm{N}), 11.41(\mathrm{~s}, 1 \mathrm{H}, \mathrm{OH}), 12.66 \mathrm{ppm}(\mathrm{s}, 1 \mathrm{H}$, $\mathrm{OH}) .{ }^{13} \mathrm{C} \mathrm{NMR}\left(\mathrm{CDCl}_{3}\right): \delta=108.8(\mathrm{C}), 111.5(\mathrm{C})$, $122.7(\mathrm{C}), 129.4(\mathrm{CH}), 130.9(\mathrm{CH}), 134.1(\mathrm{C}), 142.0$ $(\mathrm{CH}-\mathrm{N}), 152.9(\mathrm{C}-\mathrm{O}), 156.5(\mathrm{C}-\mathrm{O}), 182.4(\mathrm{C}=\mathrm{O})$, $183.0 \mathrm{ppm}(\mathrm{C}=\mathrm{O})$. Anal. calcd. for $\mathrm{C}_{11} \mathrm{H}_{6} \mathrm{~N}_{2} \mathrm{O}_{4}$ (230.18): C 57.40, H 2.63, N 12.17. Found: C 57.22, H 2.90, N 12.03.

Acknowledgments Open access funding provided by University of Natural Resources and Life Sciences Vienna (BOKU). The author would like to thank all students who have been involved in the cellulose chromophore topic over the years. BOKU's Institute of Wood Technology and Renewable Resources is acknowledged for access to physicochemical testing methods. We are grateful to Dr. Sonja Schiehser, Division of Chemistry of Renewable Resources at BOKU University, for GPC measurements.

Open Access This article is distributed under the terms of the Creative Commons Attribution 4.0 International License (http:// creativecommons.org/licenses/by/4.0/), which permits unrestricted use, distribution, and reproduction in any medium, provided you give appropriate credit to the original author(s) and the source, provide a link to the Creative Commons license, and indicate if changes were made.

\section{References}

Ameen D, Snape TJ (2015) Mechanism and application of Baker-Venkataraman $\mathrm{O} \rightarrow \mathrm{C}$ acyl migration reactions. Synthesis 47(2):141-158

Bennett AE, Rienstra CM, Auger M, Lakshmi KV, Griffin RG (1995) Heteronuclear decoupling in rotating solids. J Chem Phys 103:6951-6958

Blatt AH (1940) The fries reaction. Chem Rev 27(2):413-436

Bowden K, Chehel-Amiran M (1986) Reactions of carbonyl compounds in basic solutions. Part 11. The BakerVenkataraman rearrangement. J Chem Soc Perkin Trans 2 12:2039-2043

Crosby AH, Lutz RE (1956) A study of an oxidative-amination method for the synthesis of aminoquinones. J Am Chem Soc 78:1233-1235

Edwards M, Rourk PM, Riby PG, Mendham AP (2014) Not quite the last word on the Perkin reaction. Tetrahedron 70(40):7245-7252

Fernández-Fernández M, Sanromán MT, Moldes D (2013) Recent developments and applications of immobilized laccase. Biotechnol Adv 31(8):1808-1825
Hettegger H, Hosoya T, Rosenau T (2016) Chemistry of the redox series from hexahydroxybenzene to cyclohexanehexaone. Curr Org Chem 13:86-100. https://doi.org/10. 2174/1570179412666150710182456

Hosoya T, Rosenau T (2013) Degradation of 2,5-dihydroxy$[1,4]$-benzoquinone by hydrogen peroxide under alkaline conditions resembling pulp bleaching: a combined kinetic and theoretical study. J Org Chem 78(22):11194-11203

Hosoya T, French AD, Rosenau T (2013a) Chemistry of 2,5dihydroxy-[1,4]-benzoquinone, a key chromophore in aged cellulosics. Mini Rev Org Chem 10(3):302-308

Hosoya T, French AD, Rosenau T (2013b) Chemistry of 5,8dihydroxy-[1,4]-naphthoquinone, a key chromophore in aged cellulosics. Mini Rev Org Chem 10(3):309-315

Hosoya T, French AD, Rosenau T (2015) Chemistry of 2,5dihydroxyacetophenone, a key chromophore in cellulosic substrates. Mini Rev Org Chem 12(1):88-95

Hosoya T, Zwirchmayr NS, Klinger KM, Reiter H, Spitzbart M, Dietz T, Eibinger K, Kreiner W, Mahler AK, Winter H, Röder T, Elder T, Rosenau T (2018) Degradation of the cellulosic key chromophore 5,8-dihydroxy-[1,4]-naphthoquinone under conditions of chlorine dioxide pulp bleaching: a combined experimental and theoretical study. Cellulose 25(9):4941-4954

Houk KN, Luskus LJ (1970) The [6 + 4] 1,3-dipolar cycloaddition of diazomethane to dimethylfulvene. Tetrahedron Lett 11(46):4029-4031

Korntner P, Hosoya T, Dietz T, Eibinger K, Reiter H, Spitzbart M, Röder T, Borgards A, Kreiner W, Mahler AK, Winter H, French AD, Henniges U, Potthast A, Rosenau T (2015) Chromophores in lignin-free cellulosic materials belong to three compound classes. Chromophores in cellulosics, XII. Cellulose 22(2):1053-1062

Krainz K (2009) Mechanistic studies of chromophore formation in cellulosics. $\mathrm{PhD}$ thesis, University of Natural Sciences and Life Sciences, Vienna

Kudanga T, Nyanhongo GS, Guebitz GM, Burton S (2011) Potential applications of laccase-mediated coupling and grafting reactions: a review. Enzyme Microb Technol 48(3): 195-208

Kurtev BJ, Kratchanov CG (1969) The aldol stage of the Perkin reaction. J Chem Soc B Phys Org: 649-651. https://doi.org/ 10.1039/J29690000649

Liebner F, Ebner G, Becker E, Potthast A, Rosenau T (2010) Thermal aging of 1-alkyl-3-methylimidazolium ionic liquids and its effect on dissolved cellulose. Holzforschung 64:161-166

Luo S, Xie T, Liu Z, Wang G (2015) Laccase-mediator system: a review. Chin J Appl Environ Biol 21(6):987-995

Martin R (1992) Uses of the Fries rearrangement for the preparation of hydroxyaryl ketones. A review. Org Prep Proc Int 24(4):369-435

Muray E, Alvarez-Larena A, Piniella JF, Branchadell V, Ortuño RM (2000) 1,3-dipolar cycloadditions of diazomethane to chiral electron-deficient olefins: the origin of the $\pi$-facial diastereoselection. J Org Chem 65(2):388-396

Nowlan NV, Slavin PA, Wheeler TS (1950) The effect of bond structure on the transformation of o-aroyloxyacetoarones into o-hydroxydiaroylmethanes. Baker-Venkataraman transformation. J Chem Soc: 340-344. https://doi.org/10. 1039/JR9500000340 
Patel I, Ludwig R, Mueangtoom K, Haltrich D, Rosenau T, Potthast A (2009) Comparing soluble Trametes pubescens laccase and cross-linked enzyme crystals (CLECs) for enzymatic modification of cellulose. Holzforschung 63(6):715-720

Pawar PM, Jarag KJ, Shankarling GS (2011) Environmentally benign and energy efficient methodology for condensation: an interesting facet to the classical Perkin reaction. Green Chem 13(8):2130-2134

Potthast A, Rosenau T, Koch H, Fischer F (1999) The reaction of phenolic model compounds in the laccase-mediator system (LMS) - investigations by matrix assisted laser desorption ionization time-of-flight mass spectrometry (MALDITOF-MS). Holzforschung 53(2):175-180

Potthast A, Rosenau T, Sartori J, Sixta H, Kosma P (2002) Hydrolytic processes and condensation reactions in the cellulose solvent system N, N-dimethylacetamide/lithium chloride. Part 2: degradation of cellulose. Polymer 44(1):7-17

Rosenau T, Potthast A, Kosma P, Chen CL, Gratzl JS (1999) Autocatalytic decomposition of $N$-methylmorpholine- $N$ oxide induced by Mannich intermediates. J Org Chem 64:2166-2167

Rosenau T, Potthast A, Hofinger A, Kosma P (2001) Hydrolytic processes and condensation reactions in the cellulose solvent system $\mathrm{N}, \mathrm{N}$-dimethylacetamide/lithium chloride. Part I. Holzforschung 55(6):661-666

Rosenau T, Potthast A, Elder T, Kosma P (2002) Novel tocopheryl compounds XIII. Stabilization and first direct spectroscopic evidence of the ortho-quinone methide derived from vitamin E. Org Lett 4(24):4285-4288

Rosenau T, Potthast A, Milacher W, Hofinger A, Kosma P (2004a) Isolation and identification of residual chromophores in cellulosic materials. Polymer 45(19):6437-6443
Rosenau T, Mereiter K, Jäger C, Schmid P, Kosma P (2004b) Sulfonium ylides derived from 2-hydroxy-benzoquinones: crystal and molecular structure and their one-step conversion into Mannich bases by amine N-oxides. Tetrahedron 60(27):5719-5723

Rosenau T, Potthast A, Milacher W, Adorjan I, Hofinger A, Kosma P (2005a) Discoloration of cellulose solutions in $\mathrm{N}$ methylmorpholine- $N$-oxide (Lyocell). Part 2: isolation and identification of chromophores. Cellulose 12(2):197-208

Rosenau T, Adorjan I, Potthast A, Kosma P (2005b) Isolation and identification of residual chromomophores in cellulosic materials. Macromol Symp 223(1):239-252

Rosenau T, Ebner G, Stanger A, Perl S, Nuri L (2005c) From a theoretical concept to biochemical reactions: strain induced bond localization (SIBL) in oxidation of vitamin E. Chem Eur J 11(1):280-287

Rosenau T, Potthast A, Kosma P, Suess H-U, Nimmerfroh N (2007) First isolation and identification of residual chromophores from aged bleached pulp samples. Holzforschung 61(6):656-661

Schedl A, Zweckmair T, Kikul F, Henniges U, Rosenau T, Potthast A (2017) Aging of paper-ultra-fast quantification of 2,5-dihydroxyacetophenone, as a key chromophore in cellulosics, by reactive paper spray-mass spectrometry. Talanta 167:672-680

Suess HU (2010) Pulp bleaching today. Walter de Gruyter, Berlin, ISBN 3110207370, 9783110207378

Suess HU, Filho CL (2003) How to improve brightness stability of eucalyptus kraft pulp. In: Proceedings ABTCP 2003, 36 ${ }^{\circ}$ Congresso Internacional de Celulose e Papel, São Paulo, Brazil

Widsten P, Kandelbauer A (2008) Laccase applications in the forest products industry: a review. Enzyme Microb Technol 42(4):293-307 